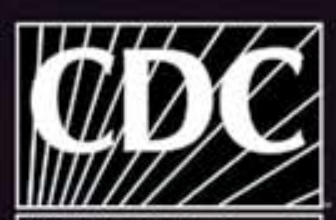

Workplace

Safety and Health
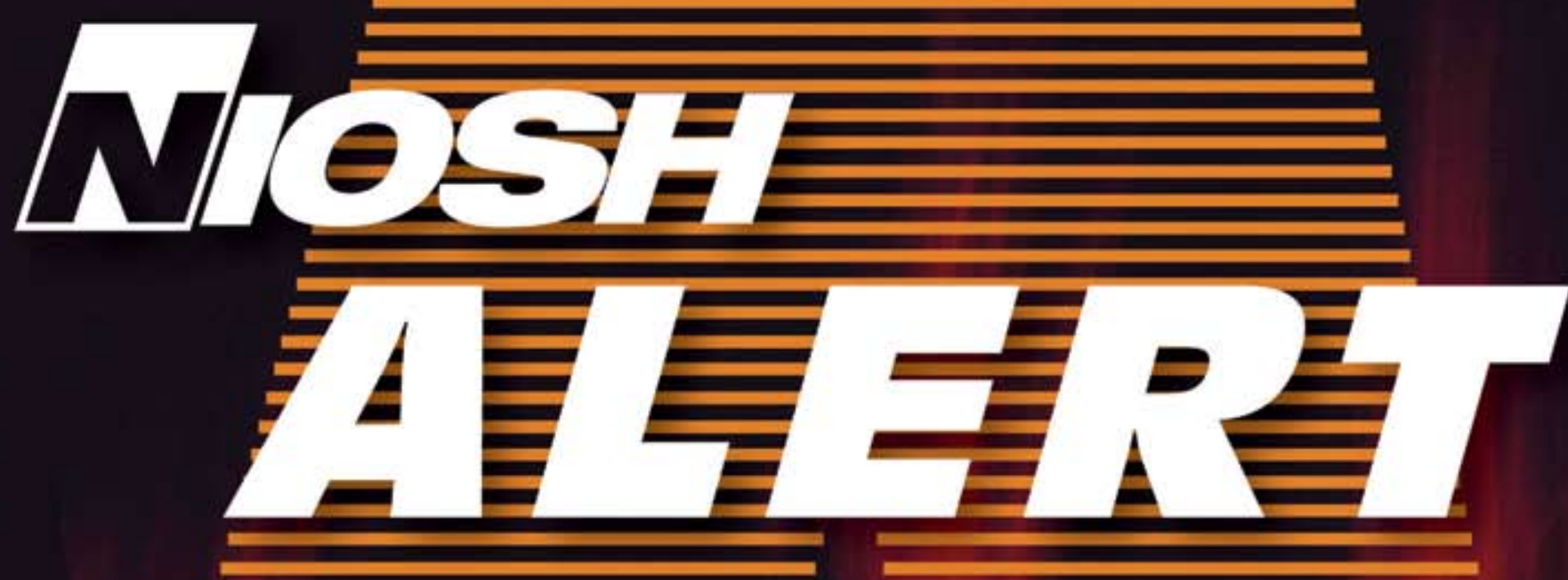

Preventing - ire-Eghter -atalities Due to

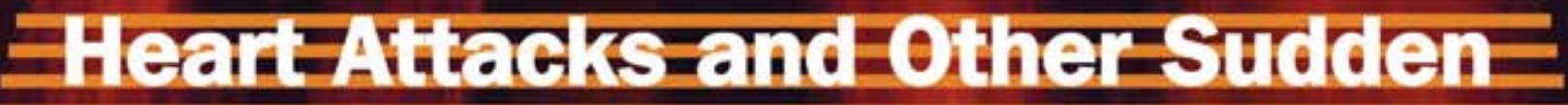
Gardiovagoular avents

\title{
DEPARTMENT OF HEALTH AND HUMAN SERVICES
}

Centers for Disease Control and Prevention

Nationall Institute for Occupational Safety and Health

Nosh 


\title{
This document is in the public domain and may be freely copied
}

\section{or reprinted.}

\section{DISCLAIMER}

Mention of any company or product does not constitute endorsement by the National Institute for Occupational Safety and Health (NIOSH). In addition, citations to Web sites external to NIOSH do not constitute $\mathrm{NIOSH}$ endorsement of the sponsoring organizations of their programs or products. Furthermore, NIOSH is not responsible for the content of these Web sites.

\section{ORDERING INFORMATION}

To receive documents or other information about occupational safety and health topics, contact $\mathrm{NIOSH}$ at

\author{
NIOSH_Publications Dissemination \\ 4676 Columbia Parkway \\ Cincinnati, OH 45226-1998
}

Telephone: 1-800-35-NIOSH (1-800-356-4674)

Fax: 513-533-8573

E-mail: pubstaft@cdc.gov

or visit the NIOSH Web site at www.cdc.gov/niosh

DHHS (NIOSH) Publication No. 2007-133

June 2007 


\section{N/OSH ALERT}

\section{Preventing Fire Fighter Fatalities Due to Heart Attacks and Other Sudden Cardiovascular Events}

\section{WARNING! \\ Fire fighters are at risk of dying on the job from preventable cardiovascular conditions.}

Fire fighters are dying on the job from preventable cardiovascular conditions.

Sudden cardiac death represents the most common cause of a fire fighter fatality. This document:

1. Provides background on fire fighting and heart disease,

2. Presents five case reports to highlight important findings,

3. Summarizes data from the NIOSH cardiovascular disease (CVD) fatality investigations, and

4. Provides recommendations (listed below) to minimize the risk of injury and death to fire fighters from cardiovascular events.

Fire Departments should take the following steps to reduce on-duty heart attacks and other sudden cardiovascular events:

- Provide medical evaluations to ensure that candidates and members are capable of performing job tasks with minimal risk of sudden incapacitation.

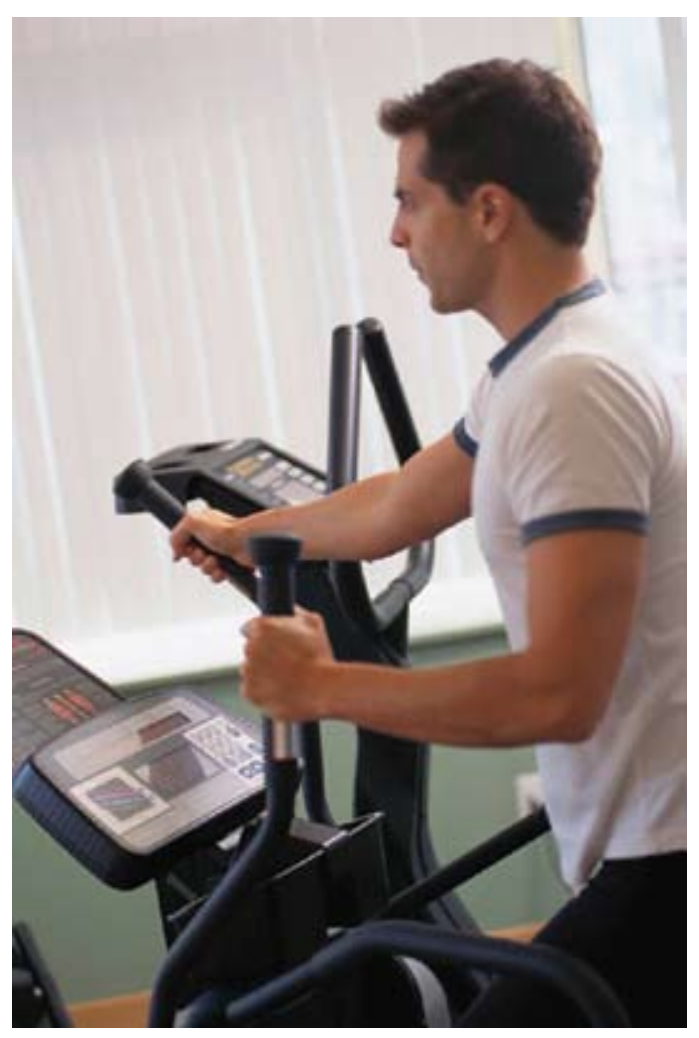

Ensure that physicians conducting the medical evaluations are knowledgeable about the physical demands of fire fighting, the essential tasks of fire fighting, and the consensus guidelines developed by the fire service. 


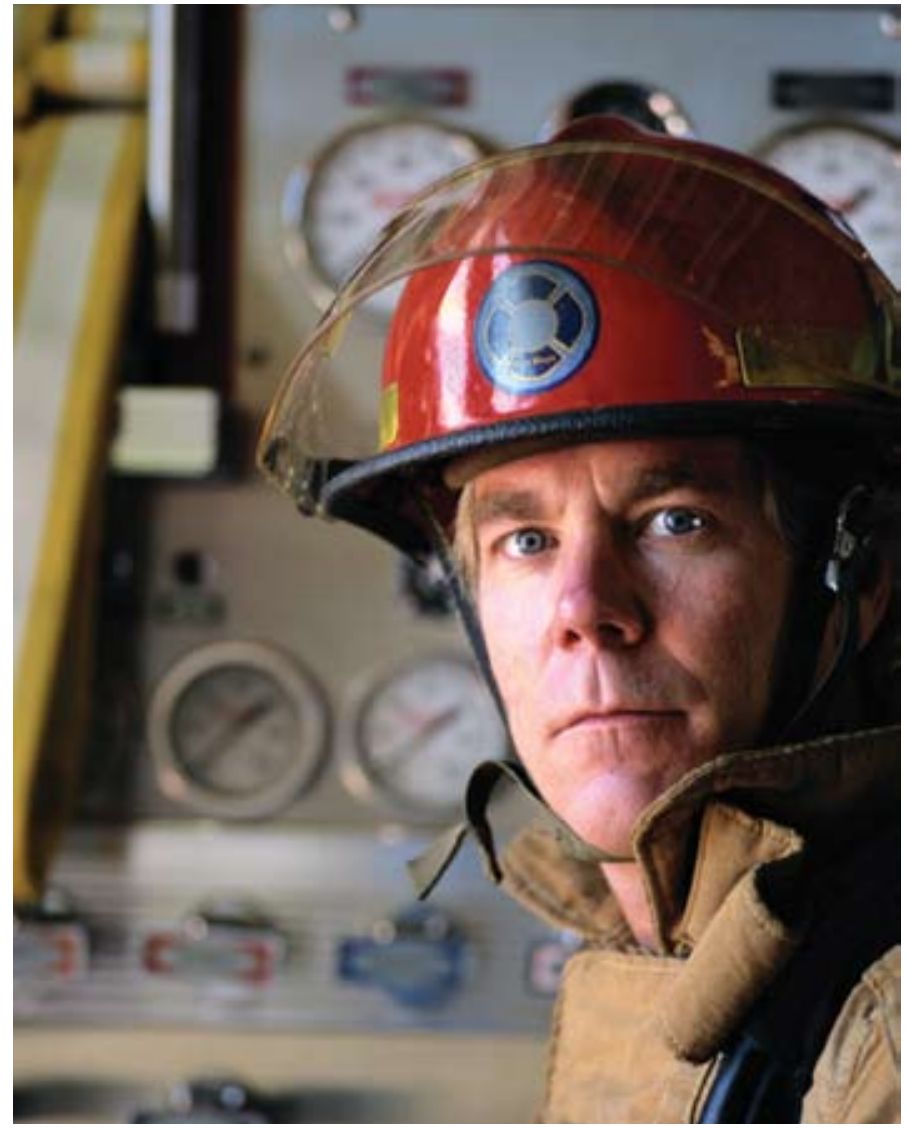

- Implement a comprehensive wellness/fitness program for fire fighters to reduce risk factors for CVD and improve cardiovascular capacity.

- Control exposure to carbon monoxide and other fire contaminants through proper management of the fire scene and proper use of respiratory protection.

- Ensure adequate staffing levels for operations to prevent over-exertion.

- Provide on-scene rehabilitation to monitor vital signs for indication of excessive cardiovascular strain, and to cool and hydrate the fire fighter.

- Implement a comprehensive hearing conservation program.
To help fire departments implement these steps, fire service agencies should conduct research on the following:

- Effectiveness of health promotion programs to reduce the incidence of heart disease among fire fighters.

- Barriers to implementing health promotion programs (both wellness and fitness).

- Effectiveness of on-scene rehabilitation to reduce cardiovascular strain.

- Risk posed to fire fighter's cardiovascular system due to occupational exposures.

For additional information, see NIOSH Alert: Preventing Fire Fighter Fatalities Due to Heart Attacks and Other Sudden Cardiovascular Events [DHHS (NIOSH) Publication No. 2007-133]. Single copies of the Alert are available free from the following:

\section{NIOSH_Publications Dissemination 4676 Columbia Parkway Cincinnati, OH 45226-1998}

$$
\begin{gathered}
\text { Telephone: 1-800-35-NIOSH } \\
\text { (1-800-356-4674) } \\
\text { Fax: 513-533-8573 } \\
\text { E-mail: pubstaft@cdc.gov }
\end{gathered}
$$

or visit the NIOSH Web site at www.cdc.gov/niosh

\section{DEPARTMENT OF HEALTH AND HUMAN SERVICES}

Centers for Disease Control and Prevention National Institute for Occupational Safety and Health 


\section{N/OSH ALERT}

\section{Preventing Fire Fighter Fatalities Due to Heart Attacks and Other Sudden Cardiovascular Events}

\section{WARNING! \\ Fire fighters are at risk of dying on the job from preventable cardiovascular conditions.}

The National Institute for Occupational Safety and Health (NIOSH) requests assistance in preventing on-duty cardiovascular deaths among U.S. fire fighters. To reduce these deaths, NIOSH recommends that fire departments and fire fighters follow established medical screening guidelines, adopt risk reduction measures during fire fighting operations, and develop and participate in comprehensive wellness/fitness programs. To bring the information and recommendations in this Alert to the attention of the fire service community, $\mathrm{NIOSH}$ requests help from the following individuals and organizations: fire commissioners, fire chiefs, State and local fire district administrators, State fire marshals, safety and health officials, health care providers (physicians, nurses, etc.), human resource specialists, unions, labor organizations, insurance companies and editors of trade journals and other publications.

\section{INTRODUCTION}

Sudden cardiac death represents the most common cause of a fire fighter fatality. In

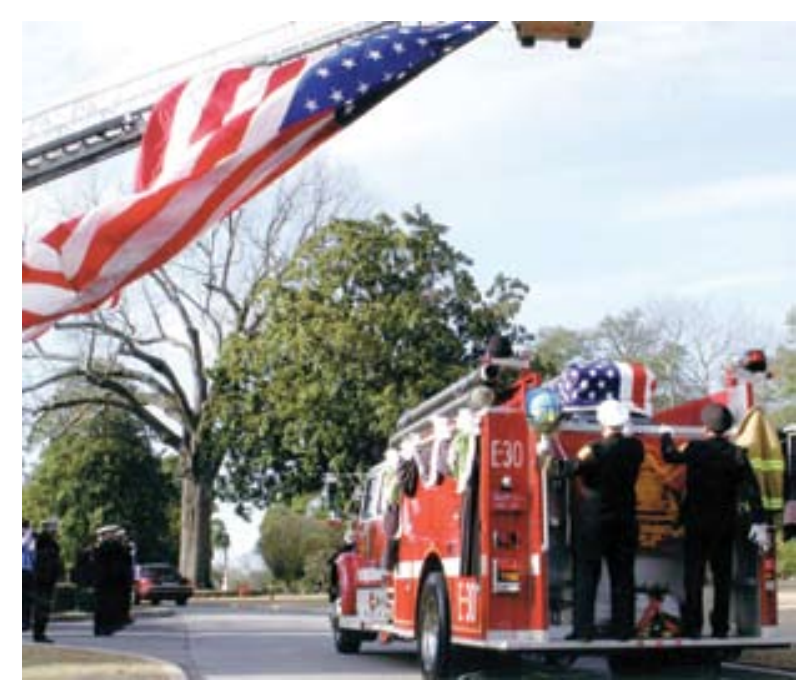

2005, the National Fire Protection Association (NFPA) reported 44\% (440/1006) of on-duty fire fighter fatalities during the tenyear period 1995-2004 were due to sudden cardiac death [Fahy 2005]. For 308 (70\%) of these 440 deaths, NFPA was able to obtain some medical information (e.g., death certificate and/or post mortem examination) about the decedent. One hundred thirty-four (44\%) of the 308 had prior known coronary artery disease (CAD) as determined by a heart attack, bypass surgery, or angioplasty/ stent procedures. However, NFPA was unable to describe the medical screening or 
fitness for duty evaluations conducted before these deaths. Therefore, additional information would be helpful to determine whether prevention efforts should be directed toward exploring reasons why fire departments and fire department physicians do not follow NFPA 1582, Standard on Comprehensive Occupational Medical Programs for Fire Departments, or toward revising the cardiovascular component of NFPA 1582.

Heart attacks and CAD are two conditions under the umbrella term, cardiovascular disease (CVD). Not all sudden cardiovascular events result in sudden death. In 2005, an estimated 765 fire fighters suffered an on-duty cardiovascular event that did not result in sudden death [Karter 2006].

In 1998, Congress funded the NIOSH Fire Fighter Fatality Investigation and Prevention Program to conduct investigations of onduty fire fighter fatalities and formulate recommendations for preventing future deaths and injuries. From 1998 to 2004, NIOSH investigated 131 (43\%) of the 304 sudden cardiac death fatalities. The NIOSH investigations included a review of the deceased fire fighter's personal medical records.

To share lessons from the NIOSH investigations, this document

1. Provides background on fire fighting and heart disease;

2. Presents five case reports to highlight important findings;

3. Summarizes data from the NIOSH cardiovascular disease (CVD) fatality investigations; and

4. Provides recommendations to minimize the risk of injury and death to fire fighters from cardiovascular events.

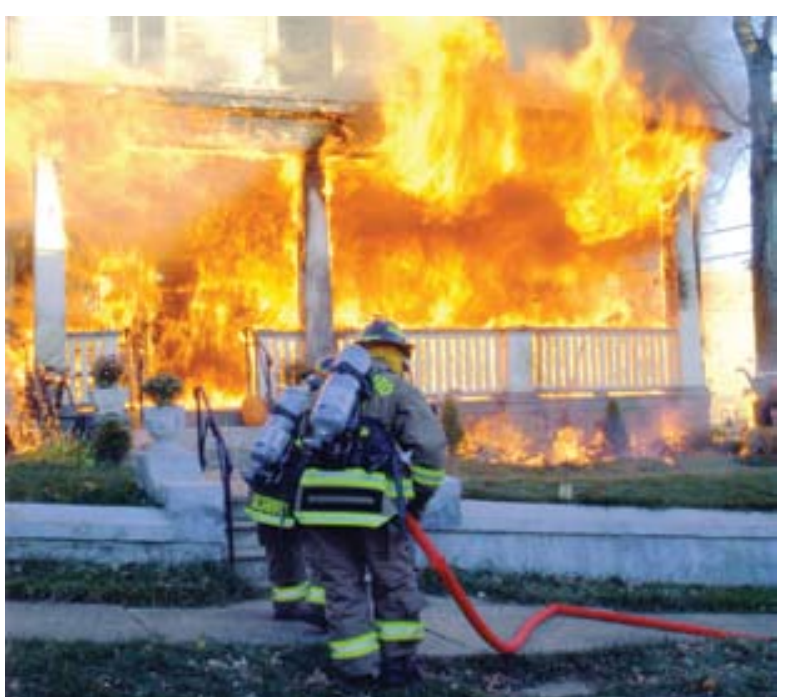

\section{BACKGROUND}

Coronary artery disease among fire fighters is due to a combination of personal and workplace factors. The personal factors are well known: age, gender, family history, diabetes mellitus, hypertension, smoking, high blood cholesterol, obesity, and lack of exercise [AHA 2007]. Not as widely known, however, is that fire fighters have exposures to workplace factors that are associated with adverse cardiovascular outcomes. Fire departments have a responsibility to implement effective prevention programs for workplace risk factors for cardiovascular disease.

\section{Cardiac and Cardiovascular Effects Associated with Fire Smoke}

Fire smoke is complex mixture of heated gases, vapors, and particulate matter. The composition of the smoke is determined not only by the fuel source, but also by fire conditions (e.g. oxygen availability, temperature, etc.) [Kulig 1991; Levin 2005]. While hundreds of decomposition products are found, two of the more common and well known gases with cardiovascular effects are carbon monoxide and hydrogen cyanide. 


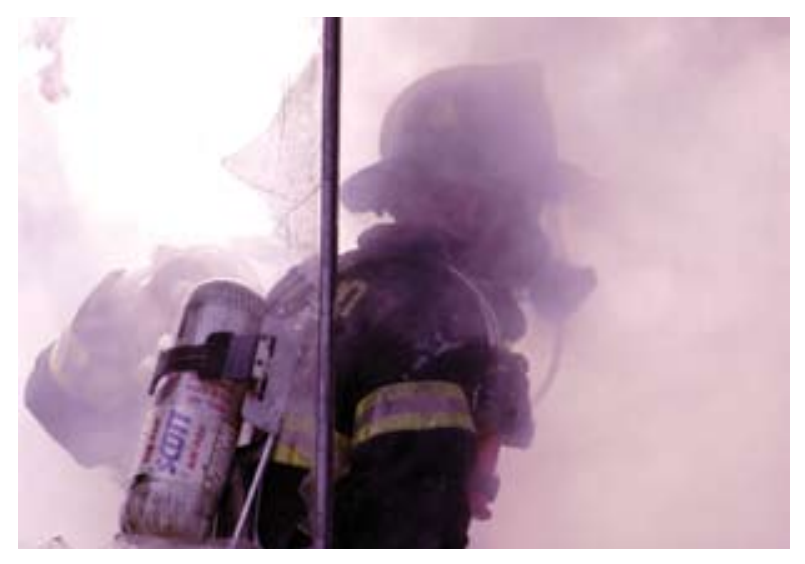

\section{Carbon Monoxide}

Carbon monoxide, a by-product of incomplete combustion, is present in virtually all fire environments. A number of studies have quantified a fire fighter's exposure during various phases of fire suppression [Gold 1978; Brandt-Rauf 1988; Jankovic 1991]. High concentrations of carbon monoxide have been documented not only during knockdown, but also during overhaul when fire fighters frequently remove their self contained breathing apparatus (SCBA) [Bolstad-Johnson 2000]. If inhaled, carbon monoxide disrupts the blood's transport of, and intracellular use of, oxygen [Ernst 1998]. The resulting hypoxia can cause myocardial injury [Satran 2005].

\section{Hydrogen Cyanide}

Hydrogen cyanide is formed during the incomplete combustion of substances containing carbon and nitrogen (e.g., paper, cotton, wool, silk, plastics, etc). Hydrogen cyanide frequently has been detected in structure fires and levels have been shown to exceed established exposure limits [Jankovic 1991; Brandt-Rauf 1988; Gold 1978]. Like carbon monoxide, hydrogen cyanide disrupts the intracellular use of oxygen, resulting in intracellular hypoxia with cardiac manifestations [Purser 1984].

\section{Particulate Matter}

Fire fighters have significant exposure to fire smoke particulate matter during fire suppression [Treitman 1980; Brandt-Rauf 1988]. Studies in the general population suggest particulate matter, as a component of air pollution, has cardiovascular effects [Brook 2004]. For example, long-term repeated exposure to elevated concentrations of particulate matter has been associated with cardiovascular mortality and the initiation/progression of atherosclerosis [Dockery 1993; Pope 2002, 2004]. In addition, short-term exposure to fine particulates has been associated with triggering heart attacks, particularly among people with pre-existing heart disease [Peters 2001; Pope 2006]. These findings have implications for the fire service given fire fighters' exposure to fire smoke particulate matter [Treitman 1980].

\section{Cardiac and Cardiovascular Effects Associated with the Work Environment}

\section{Increased Heart Rates and Heavy Physical Exertion}

A significant portion of the fire fighters' workday is spent at rest or doing light work around the fire station. However, the station's alarm may sound at any time, and fire fighters are

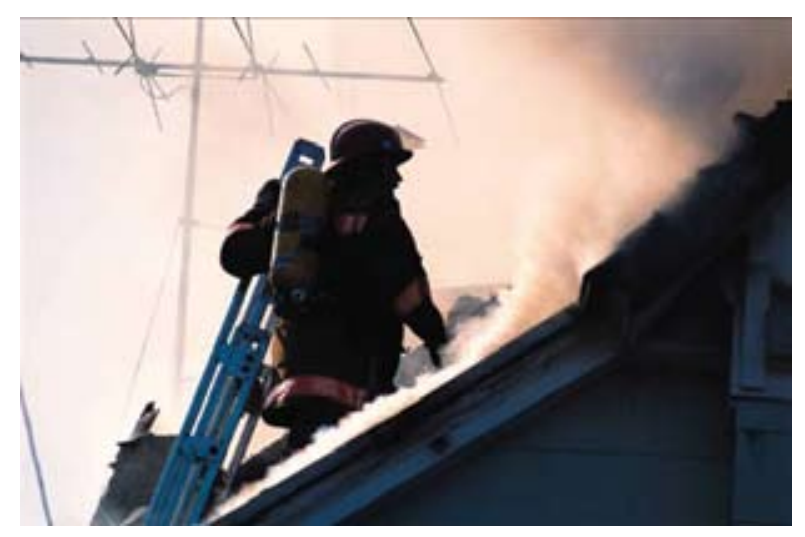


expected to rapidly deploy to the incident scene. Fire fighters react to these emergency calls with an increase in their heart rates, probably due to a surge in sympathetic nervous system activity (e.g. the flight or fight response) [Barnard 1975; Kuorinka 1981]. The increase in heart rate frequently persists through the course of fire suppression activities; a finding not surprising given the heavy physical demands of structural fire fighting [Lemon 1977; Hurley 1980; Manning 1983; Guidotti 1992; Smith 1995]. The pattern of sedentary periods interrupted by catecholamine surges and heavy physical exertion has been suspected to put fire fighters at increased risk for acute heart attacks. Epidemiologic studies in the general population report that heavy physical exertion sometimes immediately precedes and triggers the onset of acute heart attacks and

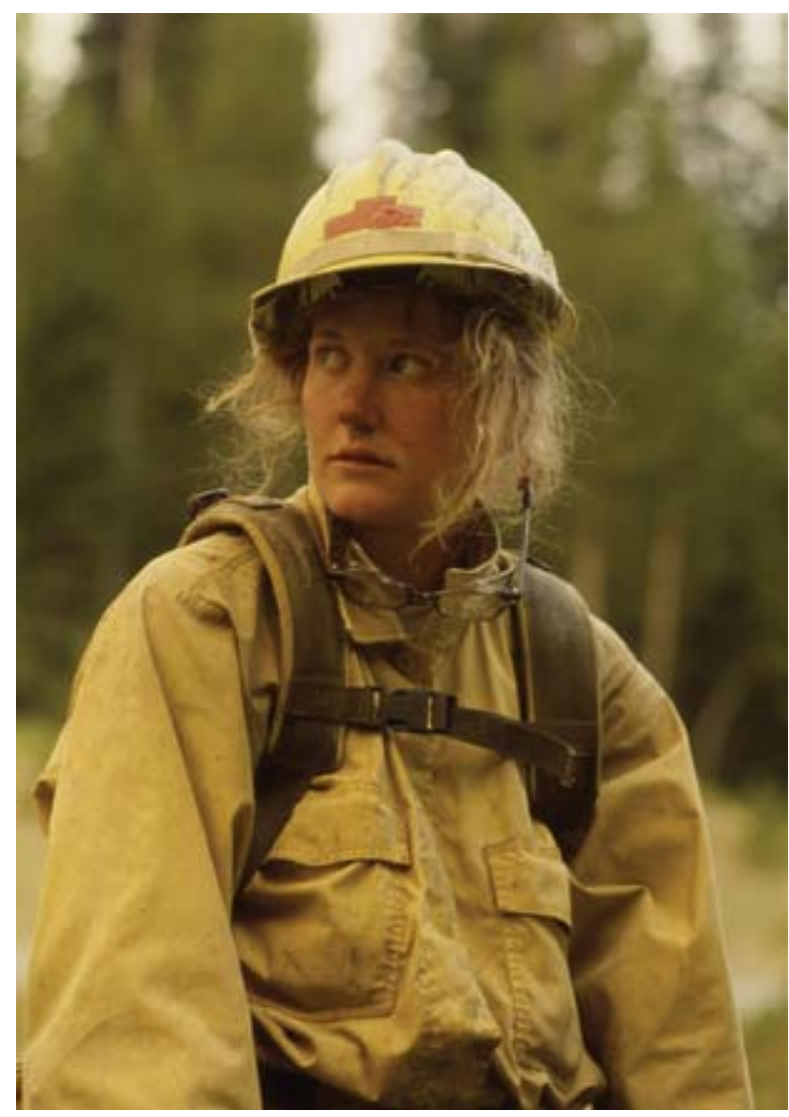

sudden cardiac death [Willich 1993; Mittleman 1993; Siscovick 1984; Tofler 1992; Albert 2000].

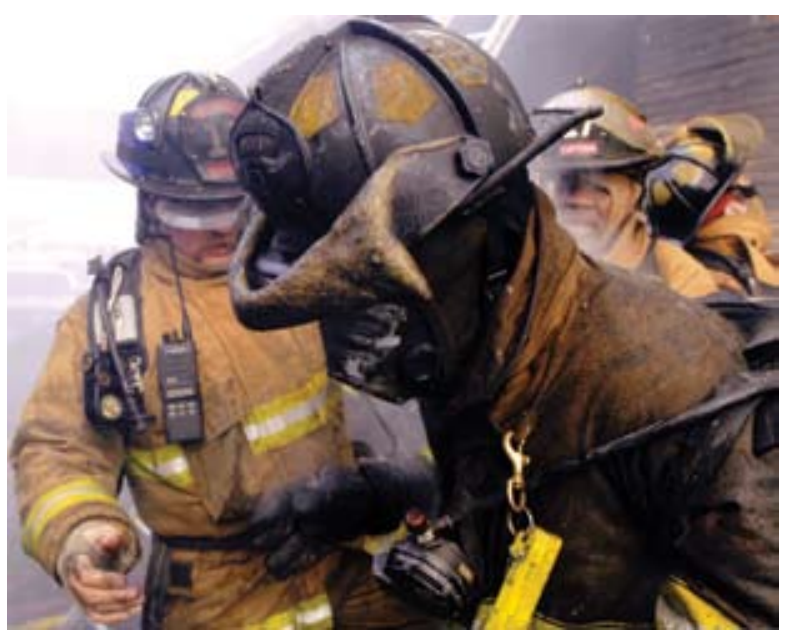

\section{Heat Stress}

Heat stress and heat illnesses are well recognized hazards of fire fighting. Fire suppression can increase body temperature resulting in sweating and fluid loss, which can cause serum electrolyte changes, lower stroke volume (the volume of blood pushed during each contraction of the heart), or lower cardiac output [Rossi 2003; Smith 2001; Costrini 1979]. Heat stroke has been reported to increase the risk of myocardial ischemia, arrhythmias, and conduction abnormalities [Akhtar 1993].

\section{Noise Exposure}

Fire fighters' noise exposures are obvious: sirens, air horns, diesel engines, and the roar of a large structure fire itself. During emergency operations, sound levels exceeding 120 decibels have been measured [Tubbs 1995]. Studies of community and occupational groups have found an association between noise exposure and hypertension, and possibly an association with ischemic heart disease [Van Kempen 2002; Davies 2005; Willich 2006; McNamee 2006]. It 
is important to note that fire fighters' noise exposure (short duration, high intensity) differs from that studied in community and in other occupational groups [lower intensity for a longer duration (e.g. full-shift)]. However, given the extent of the noise-induced hearing loss found in fire fighters, it is plausible that noise exposure increases the risk of hypertension and possibly ischemic heart disease among fire fighters [Tubbs 1995].

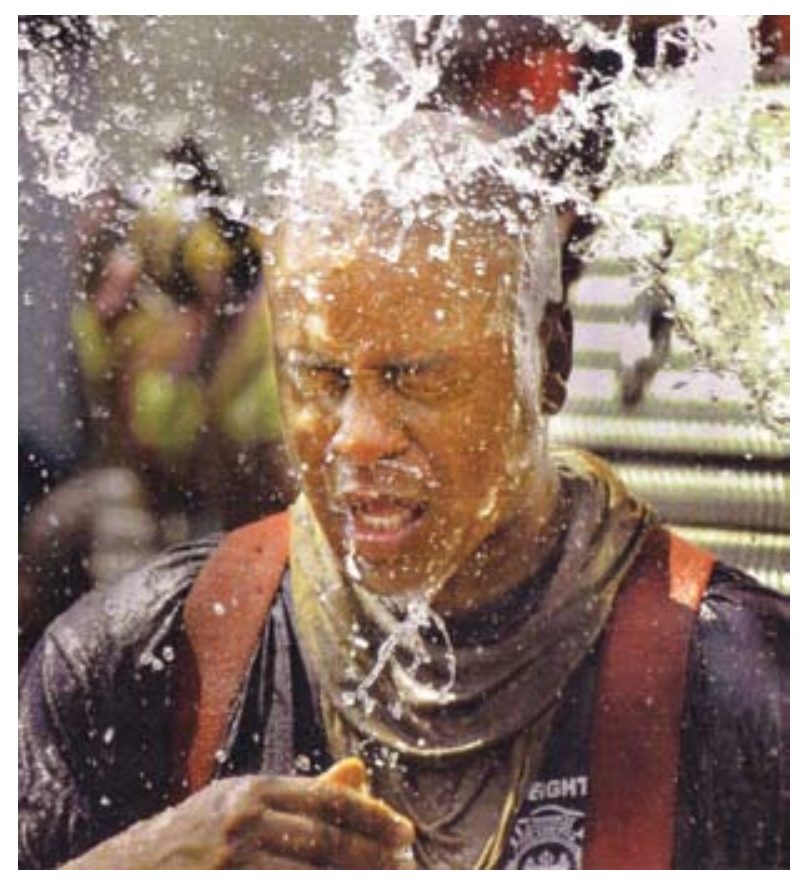

\section{Shift Work and Overtime}

Several studies suggest a modest association between rotating shifts (e.g., a week of days, a week of evenings, a week of nights, with weekends off) and heart disease [Steenland 2000]. Because most career fire departments work 24-hour shifts and volunteers fire fighters do not work shifts at all, these findings may have limited application to the fire service. A 24-hour shift, however, is long, stressful, and fatiguing. The literature also suggests long hours can increase blood pressure and lead to increased heart disease, independently of other stressful conditions at work [Steenland 2000].

\section{Environmental Tobacco Smoke}

In 2006, the Surgeon General confirmed a causal relationship between exposure to secondhand smoke and increased risks of coronary heart disease morbidity and mortality [USDHHS 2006]. An estimated 46,000 cardiac deaths occur each year due to secondhand smoke in the United States [Cal/ EPA 2005]. Since not all fire stations are smoke free, involuntary exposure to tobacco smoke continues to present cardiovascular risks for fire fighters.

\section{Fire Fighting and Heart Disease}

Over 25 published studies examine the relationship between heart disease and fire fighting. Results of these studies are conflicting (e.g., some studies support the association while others do not). In 1995, Guidotti published a review of the fire fighter mortality literature. He concluded, "Sudden death, myocardial infarction, or fatal arrhythmia occurring on or soon after near-maximal stress of the job are likely to be [work] related..." [Guidotti 1995]. It is important to recognize, however, the limitations of the scientific method used in these studies. The major concern is a problem known as the healthy worker effect (HWE) [Choi 1992]. This problem arises because working populations are usually selected for employment in such a way that they have better health (corresponding to a lower death rate) than the general population to whom the workers are compared. For example, before placement, fire fighter candidates are screened for many cardiovascular conditions and risk factors (e.g., diabetes and hypertension). This leads to a strong healthy hired effect, one component of the HWE [Arrighi 1994]. In 2000, Choi re-assessed 23 standardized mortality ratio studies addressing the relationship between fire fighting and heart 
disease after attempting to control for the HWE. He concluded that, "(1) there is strong evidence of an increased risk of death overall from heart disease among firefighters; .... (3) there is insufficient evidence, even after considering the HWE, for a relationship between firefighting and any heart disease subtype, such as acute myocardial infarction" [Choi 2000].

\section{CURRENT STANDARDS}

\section{(4) National Fire Protection Association (NFPA)*}

The NFPA develops voluntary, consensusbased codes and standards to protect fire fighters and civilians from injuries and death due to fire or other hazards. The following NFPA standards address fire fighter medical screening and fitness-for-duty evaluations.

NFPA 1500, Fire Department Occupational Safety and Health Program, stipulates that fire departments establish an occupational safety and health and committee to research, develop recommendations, as well as study and review matters pertaining to occupational health. The standard also stipulates requirements for standby emergency medical care at a minimum of basic life support level at certain incidents and the requirement at all incidents for the incident commander to evaluate the need for emergency medical care and patient transportation. The standard also requires compliance with NFPA 1582, and 1583 Standards.

NFPA 1582, Standard on Comprehensive Occupational Medical Program for

'The NFPA logo is a registered trademark of the National Fire Protection Association, Quincy, MA 02169.
Fire Departments, stipulates that all fire departments establish a medical evaluation procedure for candidates and current members. The standard requires a postoffer/pre-placement, annual, and returnto-duty medical evaluation by a qualified physician. For candidates, the standard lists medical conditions as category $A$ (precluding) and category B (could be precluding). The standard is more flexible for current members based on the type of severity of their medical condition and upon their specific job tasks [NFPA 2007].

NFPA 1583, Standard on Health-related Fitness Programs for Fire Fighters, stipulates that fire departments establish and provide a health-related fitness program that enables members to develop and maintain a level of health and fitness to safely perform their assigned functions [NFPA 2000].

\section{Occupational Safety and Health Administration (OSHA)}

OSHA promulgates and enforces occupational safety and health regulations. Public employees (State and local workers) are exempt from these regulations; unless the State has an OSHA approved occupational safety and health plan. If a fire department operates in a State Plan State, it must comply with OSHA or State standards when they are more stringent. The OSHA standard regarding respiratory protection [29 CFR $1910.134]^{\dagger}$ is relevant to on-duty sudden cardiac death among fire fighters because it requires employers to establish and maintain a respiratory protection program. One portion of this respiratory protection standard requires the wearer of the respirator to be medically cleared. While this clearance

\footnotetext{
${ }^{\dagger}$ Code of Federal Regulations. See CFR in references.
} 
can be as simple as the completion of a brief medical questionnaire, the standard requires that a health care provider evaluate symptomatic employees and employees with heart or lung conditions. The standard also requires that if a fire fighter must enter an environment that is immediately dangerous to life and health (IDLH) (e.g., interior structural fire), at least two fire fighters must enter the area together and remain in visual, physical, or vocal contact with one another at all times. In addition, at least two properly equipped and trained fire fighters must be positioned outside the IDLH atmosphere, account for the interior teams, and remain capable of rapid rescue of the interior team.

Other OSHA standards applicable to fire fighters include Hazardous Waste Operations and Emergency Response [29 CFR 1910.120] and Fire Brigades [29 CFR 1910.156]. The Hazardous Waste Operations and Emergency Response standard requires a medical examination for HAZMAT members at least once every 12 months unless the attending physician believes a longer interval is appropriate (but never longer than every two years). Guidance on the content of that medical examination has been developed by NIOSH, OSHA, the United States Coast Guard, and the Environmental Protection Agency [NIOSH 1985]. The Fire Brigade standard precludes fire brigade members with known heart disease, epilepsy, or emphysema from participating in emergency activities. However, this preclusion may be waived when a physician certifies that the employee is fit to participate.

\section{International Association of Fire Fighters (IAFF) and International Association of Fire Chiefs (IAFC)}

The IAFF, a labor union, and the IAFC, a management organization, are devoted to the safety and health of their members, among other fire service issues. In the late 1990s, they worked together to publish the following guidance documents:

The Fire Service Joint Labor Management Wellness-Fitness Initiative. This guidance document presents a comprehensive wellness-fitness program with five main components: (1) medical (e.g., screening tests), (2) fitness, (3) medical/fitness/injury rehabilitation, (4) behavioral health, and (5) data collection and reporting. [IAFF/IAFC 1997]. The last two versions of NFPA 1582, Standard on Comprehensive Occupational Medical Program for Fire Departments, have been consistent with this initiative.

Candidate Physical Ability Test. One component of the test includes a post-offer/ pre-placement medical evaluation for fire fighter candidates. This medical evaluation screens candidates for conditions associated with sudden incapacitation [IAFF/IAFC 1999].

Peer Fitness Trainer Certification. This certification program ensures the trainer is not only knowledgeable about the health and fitness needs of the North American Fire Service, but also possesses the skills necessary to design and implement wellness and fitness programs.

\section{United States Fire Admin- istration and the National Volunteer Fire Council}

The mission of the United States Fire Administration (USFA) (a Federal Agency within the Department of Homeland Security) is to reduce life and economic losses due to fire and related emergencies. The National Volunteer Fire Council (NVFC) is a non-profit membership association representing the 
interests of the volunteer fire, emergency medical service, and rescue services. In 2004, the NVFC partnered with the USFA to publish a Health and Wellness Guide for the Volunteer Fire Service. At the same time, the NVFC initiated its Heart-Healthy Firefighter Program [NVFC 2004a,b]. The guide outlines program components that can be used by volunteer departments including screenings, examinations, immunizations, education, behavioral modification, and fitness programming. Both the document and the initiative are efforts to fulfill the NVFC goal of reducing heart-related on-duty fire fighter deaths by $25 \%$ by the year 2008 .

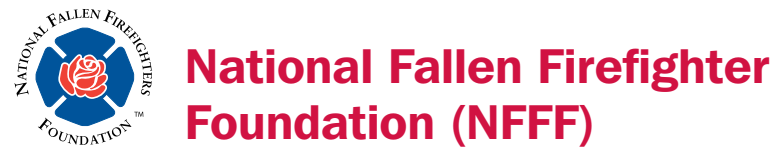

The NFFF is a non-profit organization devoted to honoring and remembering America's fallen fire fighters and assisting their families and coworkers. In 2004, the NFFF launched its Everyone Goes Home program to prevent fire fighter line-of-duty deaths and injuries. The program developed 16 life safety initiatives, which included, "develop and implement national medical and physical fitness standards that are equally applicable to all firefighters, based on the duties they are expected to perform." The program's Web site provides training materials for individual fire department to develop health and wellness programs [NFFF 2007].

\section{CASE REPORTS}

The following factors frequently were involved with the on-duty sudden cardiac deaths among fire fighters investigated by NIOSH.

1. Inadequate medical evaluations of candidates or members.
2. Insufficient work restrictions following the identification of specific medical conditions.

3. Absence of, or nonparticipation in, an adequate fitness or wellness program.

4. Delayed access to, or inadequate training on, automated external defibrillators (AED).

5. The sudden death of the fire fighter while driving either a fire department vehicle or the fire fighter's personal vehicle while responding to an emergency incident.

The five case reports below describe fire fighter fatalities due to sudden cardiac events that were investigated by the $\mathrm{NIOSH}$ Fire Fighter Investigation Team. Each case illustrates one of the factors noted above.

\section{Case 1-Volunteer Fire Fighter Suffers Sudden Cardiac Death During a Trench Rescue [NIOSH 2000]}

A 47-year-old male volunteer fire fighter collapsed after performing strenuous physical activity at the site of a trench rescue. Despite cardiopulmonary resuscitation (CPR) and advanced life support (ALS) administered by crew members, ambulance service personnel, and in the hospital's emergency department, the fire fighter died. The death certificate, completed by the fire fighter's personal physician, listed acute myocardial infarction, commonly known as a heart attack, as the immediate cause of death. Pertinent autopsy results included the presence of a thrombosis (blood clot) in one of his coronary arteries, coronary atherosclerosis (plaque), and fibrosis consistent with previous heart attacks. Before his death, the fire fighter did not have any known heart 
disease, although he had many known risk factors for atherosclerotic coronary artery disease (CAD) [AHA 2006]. These included male gender, age greater than 45 years, high blood pressure (hypertension), high blood cholesterol, diabetes mellitus (non-insulin dependent), a current history of smoking, and physical inactivity. The fire fighter's primary care physician was either unaware of his patient's status as a volunteer fire fighter or was unaware of published guidelines regarding fire fighter medical clearance. If current guidelines had been followed, these CAD risk factors would have been identified during the fire department's medical evaluation program and an exercise stress test would have been performed [NFPA 2007]. This volunteer fire department, however, did not require medical evaluations or medical clearances for its members.

\section{Case 2-Career Fire Fighter Suf- fers Sudden Cardiac Death After Completing Physical Ability Test [NIOSH 2001]}

A 55-year-old Captain was placed on restricted duty by the fire department physician for not passing his physical ability test and for not passing his medical evaluation due to severe CAD. The Captain was seen shortly thereafter by his personal physician who released him to work with no restrictions despite signs of exercise-induced cardiac ischemia (reduced blood flow to the heart muscle). The fire department did not require the fire department physician to approve return-to-work releases signed by primary care physicians. After presenting his work release to the fire department, the Captain re-took the physical ability test. Wearing full bunker gear, he completed the following tasks: hose hoist, hose pull, dummy (manikin) drag, and hydrant hook-up/disconnect. During these tasks, he began to have trouble breathing, but he continued the test. The last portion of the physical ability test was donning the 22-pound SCBA and climbing 128 steps. After completing this task, the Captain exited the drill tower; he became unresponsive, stopped breathing, and was pulseless. Despite CPR and ALS, the Captain died. The autopsy listed cardiac arrhythmia due to myocardial ischemia due to "coronary artery disease" as the cause of death. Based on current guidelines, the Captain's personal physician should not have released him to unrestricted duty [NFPA 2007].

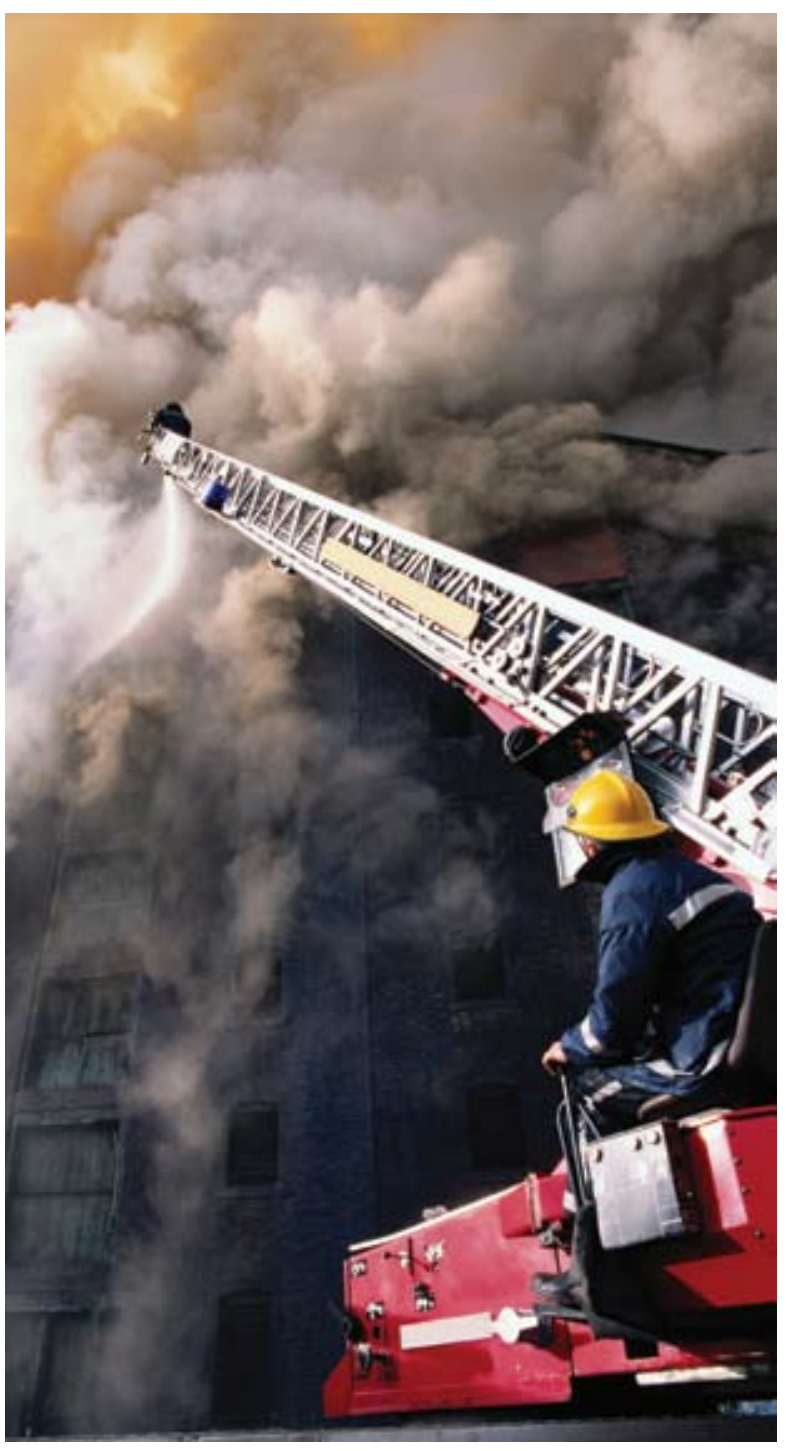


Case 3-Career Fire Fighter Has Sudden Cardiac Death and Dies During Live Fire Training [NIOSH 2003]

On April 10, 2002, a 56-year-old male career Captain carried pallets and straw to initiate a training fire in a two-story apartment building. The pallets each weighed about 25 pounds, and each bale of straw weighed 50 pounds. After the materials were in place, the Captain (wearing full turnout gear and breathing air from an SCBA) finished igniting the training fire and exited the structure. Shortly after doffing his SCBA, he collapsed. Despite CPR and ALS, the Captain died. The autopsy listed the cause of death as probable cardiac arrhythmia secondary to ischemic heart disease caused by severe coronary artery atherosclerosis. The Captain had the following risk factors for CAD: male gender, age over 45, family history of CAD, high blood cholesterol, physical inactivity and mild obesity. Two months before his death, the Captain participated in an annual physical examination performed by a clinic that was under contract with the fire department. The exam included a bicycle stress test on which the Captain lasted for 5 minutes reaching $81 \%$ of his maximum heart rate, and achieved an aerobic capacity of 27.4 milliliters per kilogram per minute $(\mathrm{mL} / \mathrm{kg} / \mathrm{min})$ or 7.8 metabolic equivalents (METS). A 12-lead electrocardiogram conducted throughout the test did not reveal any blood flow changes (ischemia) to the heart muscle, and the Captain was cleared for full duty.

While this fire department required members to receive an annual medical evaluation, its fitness program was voluntary. The Captain was one of many fire fighters who did not participate. Based on the bicycle stress test, the Captain's exercise capacity was below that which is typically needed to perform the essential job tasks of structural fire fighting [Gledhill 1992]. This Captain's relatively low aerobic capacity not only had job capacity implications, but also increased his risk of sudden cardiac death [Paffenbarger 1993; Sandvik 1993].

\section{Case 4-Volunteer Fire Chief Suf- fers a Probable Heart Attack and Dies After Performing Service Call [NIOSH 2004]}

On November 18, 2002, a 50-year-old male volunteer Fire Chief responded to a medical call with his fire department, then responded to a separate incident involving a carbon monoxide alarm at a private residence. The Chief responded to this second incident alone and found no carbon monoxide. Upon returning to the fire station, he complained to his wife by telephone of not feeling well. His wife called 911 while the Chief retrieved an oxygen cylinder and a non-rebreather mask from the fire department's engine parked in the station's apparatus bay. The Chief was self administering 100\% oxygen when a certified emergency medical technician arrived. About 8 minutes later, the Chief lost consciousness. CPR was initiated, but the fire fighters who were performing the CPR did not have access to an AED. The fire department's only AED was on the ambulance that had not yet returned from the previous medical call. About 15 minutes after the Chief first expressed symptoms to his wife, about 12 minutes after the first fire fighter/EMT was on-scene, and about 5 minutes after losing consciousness, an AED from a neighboring fire department's ambulance arrived on-scene. The AED was attached to the Chief and four shocks were delivered. Despite CPR and ALS administered on-scene, during transport, and in the 
hospital's emergency department, the Chief died. The autopsy revealed arteriosclerosis, with $95 \%$ occlusion of the left main coronary artery and $90 \%$ occlusion of the right coronary artery. Rapid access to an AED is probably the single most important determinant of outcome for an out-of-hospital cardiac arrest with ventricular fibrillation [Stiell 1999a,b].

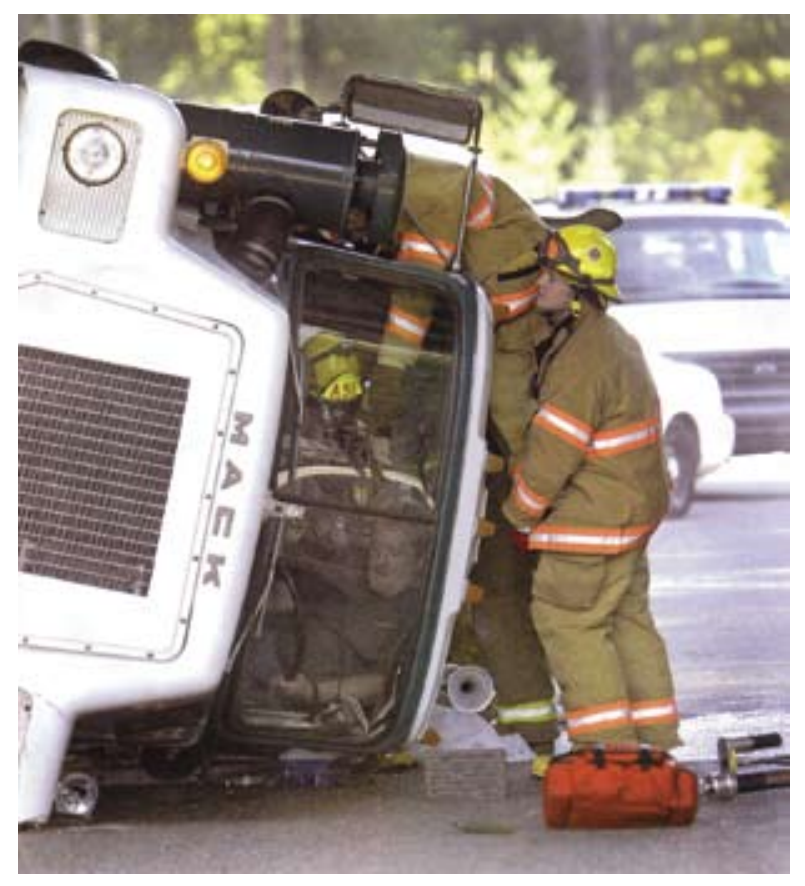

Case 5-Career Fire Chief Suffers Sudden Cardiac Death While Returning to the Fire Station After a Structure Fire [NIOSH 2005]

On December 13, 2004, a 56-year-old male career Fire Chief responded to three fire calls, including two residential fires and one commercial fire. After the last fire, the Chief returned to cordon off the scene. As he was driving the rescue truck back to the fire station, he collapsed. The truck left the roadway, struck a culvert, and came to a stop. Witnesses called 911 and removed the Chief from the truck. Despite CPR and ALS performed by bystanders, crew members, ambulance service paramedics, and hospital emergency department personnel, the Chief died. The death certificate, completed by the Deputy Coroner, listed cardiorespiratory arrest due to ASCVD [atherosclerotic cardiovascular disease] as the cause of death. No autopsy was performed. This case illustrates that sudden incapacitation by a fire fighter while performing critical functions (e.g. driving, fire suppression, rescue, etc.) jeopardizes the safely not only themselves, but other fire fighters and civilians.

\section{DATA FROM THE NIOSH CVD INVESTIGATIONS}

\section{Medical Evaluations}

Of the 131 fire departments where NIOSH investigated a cardiovascular disease (CVD) fatality, 93 (71\%) performed candidate medical evaluations. However, only 41 (31\%) conducted annual, or even periodic, medical evaluations for all members participating in fire suppression. Fire departments not providing candidate and member medical evaluations are not following the recommendations of NFPA, and the fire service management and union organizations, which support mandatory post-offer/pre-placement medical evaluations for candidates and annual medical evaluations for members [IAFF/IAFC 1997, NFPA 2000, NFPA 2007].

\section{Medical Clearance}

One-hundred-five (80\%) of the 131 fire departments where NIOSH investigated a CVD fatality required a return-to-work clearance after an injury or illness. Over half of these fire departments (61/105 or 58\%) allowed the fire fighter's personal physician to make the return-to-work determination. Allowing 
a fire fighter's personal physician to make this determination can be problematic for two reasons. First, primary care physicians may not be familiar with the heavy physical demands of fire fighting or their potential for hazardous exposures. Second, they may not be aware of the consensus medical guidelines developed by fire service medical experts. Therefore, fire departments should either

1. Provide the consensus medical guidelines and the physical and aerobic requirements of the job to the primary care physician; or

2. Require the fire department physician review return-to-duty clearances. [NFPA 2007].

\section{Fitness-Wellness Programs}

Fifty-one (39\%) of the 131 fire departments where NIOSH investigated a CVD fatality had voluntary fitness programs, but only 11 (8\%)

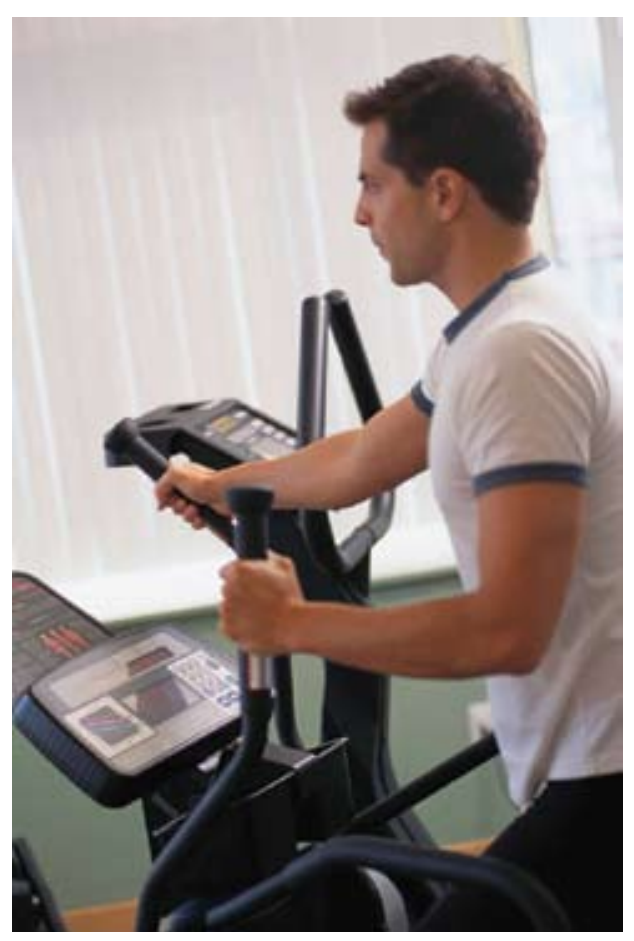

had mandatory participation. Maintaining a fire fighter's physical condition is an important issue in the fire service and a key element in enhancing overall, and specifically heart, health [IAFF/IAFC 1997]. Various researchers have reviewed worksite health promotion programs and come to differing conclusions regarding their clinical effectiveness [Glasgow 1999; Pelletier 1996]. Although the components of these worksite programs vary by study, programs that include individualized risk reduction for high-risk employees within the context of a comprehensive program seem to hold the most promise for positive clinical and cost outcome [Pelletier 2001]. The guidelines developed by both the IAFF/IAFC and the NFPA involve a comprehensive program with individualized assessment for all fire fighters. The guidelines go on to recommend rehabilitation for fire fighters with heart disease or risk factors for CAD. Participation in these fitness/wellness programs should reduce the number of both on-duty and offduty fire fighter heart attacks and sudden cardiac events.

\section{Automated External Defibrillators (AEDs)}

$\mathrm{NIOSH}$ identified 4 (3\%) cases where the lack of rapid access or the inadequate function of the AED contributed to the death of the fire fighter. Rapid defibrillation after an out-ofhospital cardiac arrest with ventricular fibrillation is probably the single most important determinant of outcome [Stiell 1999a,b]. During the first 8 minutes of resuscitation, survival is reduced by $10 \%$ for each minute of defibrillation delay [Valenzuela 1997; White 1998; Nichol 1999; Finn 2001]. The American Heart Association (AHA) considers early defibrillation as an essential link in the chain of survival [AHA 2005]. 


\section{Sudden Cardiac Death While Operating A Vehicle}

Of the 131 cases where NIOSH investigated a CVD fatality, 14 involved the death of the fire fighter while driving either a fire department vehicle or the fire fighter's personal vehicle. These deaths occurred while traveling to or from the emergency incident. None of these 14 fire departments were following consensus guidelines with regard to medical evaluation or medical clearance [NFPA 2007]. Although fire department property was damaged or destroyed in several incidents, no other fire fighters or civilians were hurt during the ensuing motor vehicle crashes. However, these findings suggest that, without intervention, a fire fighter suffering an acute cardiac emergency while driving a fire department vehicle will eventually injure other fire fighters or civilians. NIOSH believes this risk can be reduced by implementing recommended medical evaluations.

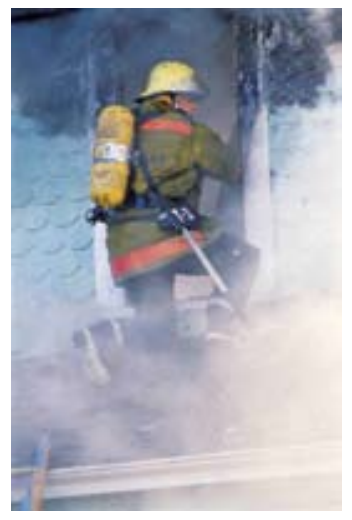

\section{Carbon} Monoxide

Carboxyhemoglobin (COHB) levels were analyzed for only 39 $(30 \%)$ of the 131 deaths NIOSH investigated. COHB levels ranged from $0 \%$ to $10 \%$. These levels are unlikely to have been directly responsible for any of the 39 fatalities. However, for fire fighters with significant $\mathrm{CAD}, \mathrm{COHB}$ levels between $5 \%$ and $10 \%$ may have been a contributing factor. Low levels of $\mathrm{COHB}$ $(2.4 \%$ to $5.6 \%)$ have been linked to reduced-time to angina and reduced-time to ischemic changes on electrocardiogram in subjects with CAD, suggesting a clinical effect [Allred 1989, 1991; USEPA 1992].
COHB may not be measured in deceased fire fighters for several reasons. Most commonly, the fire fighter was not responding to an incident involving a fire or the fire fighter was not perceived to have been downwind of the smoke plume. However, there are many unrecognized sources of carbon monoxide among fire fighters. These include environmental tobacco smoke, diesel exhaust in the firehouse, or even diesel exhaust from the fire department engine operating at the fire scene. Due to these unrecognized exposures and the potential for adverse cardiac effects among susceptible individuals, $\mathrm{NIOSH}$ recommends additional research directed toward the role carbon monoxide plays during on-duty sudden cardiac deaths.

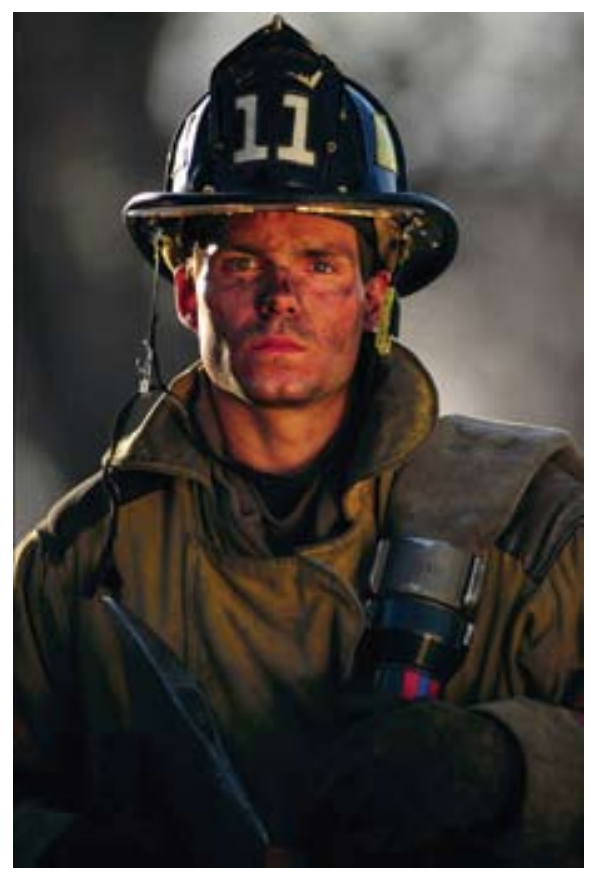

\section{Work-relatedness}

In 1999, NIOSH presented evidence from its fatality investigations suggesting that fire fighter CVD fatalities were triggered by work activities [Hales 1999]. The majority of onduty fire fighter CVD fatalities occurred in the afternoon or evening hours (Figure 1). 


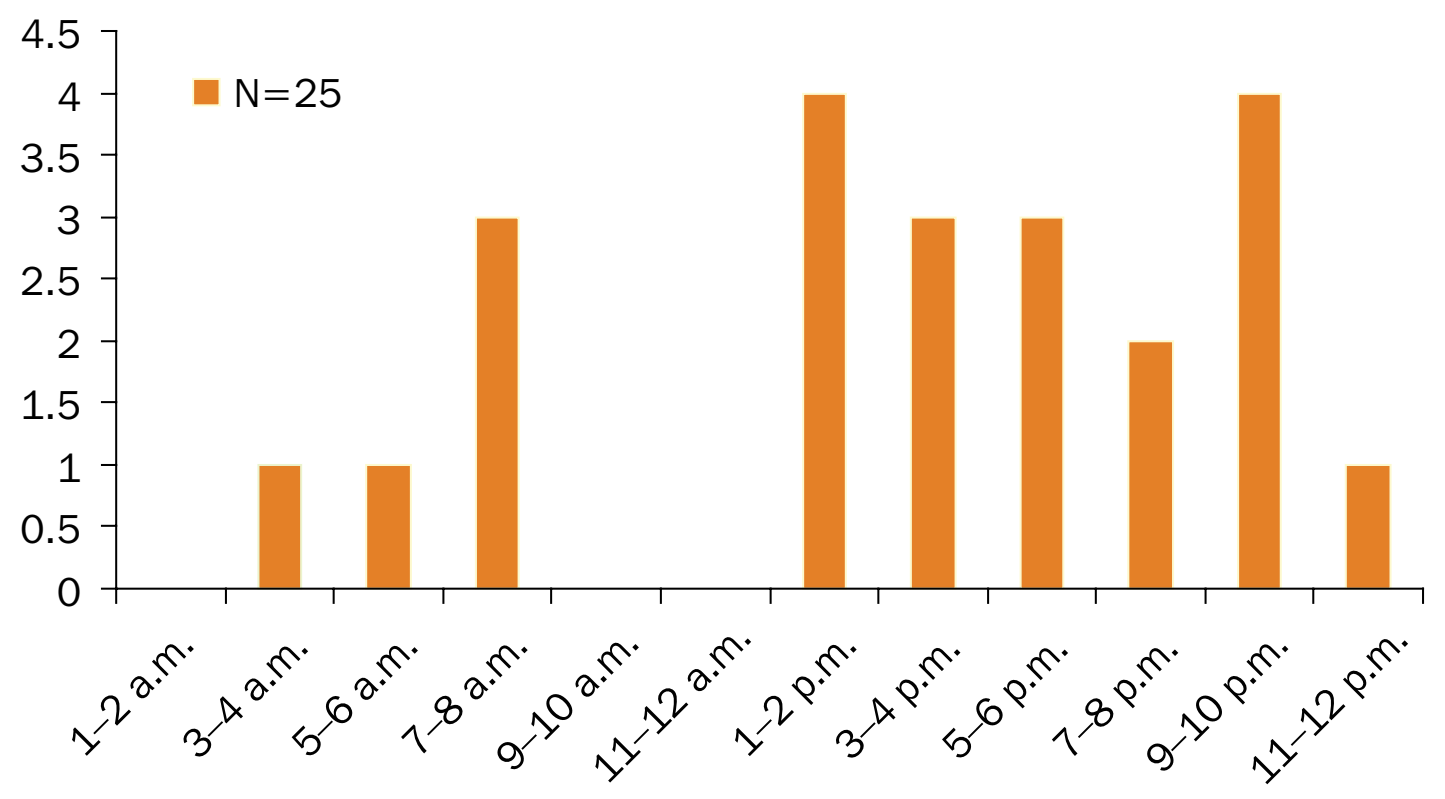

Figure 1. Fire fighter fatalities due to cardiovascular disease by time of the event.

This is in stark contrast to the circadian rhythm of coronary heart disease deaths in the general population, in which the majority of these deaths have been found to occur in the early morning hours [Elliott 2001]. An analysis of fire fighters' activities immediately preceding their sudden deaths showed that over $75 \%$ of the deaths occurred while traveling to or from an incident, at an incident, or during training activities (Figure 2). These activities are known to produce high heart rates and elevated blood pressures, which can be attributed to alarm response or performing physically demanding tasks.

These findings led to a formal analytic epidemiological study [Kales 2003]. Using data from the $\mathrm{NIOSH}$-investigated CVD fatalities, Kales and his colleagues reported a statistical difference in the temporal pattern of sudden cardiac deaths in fire fighters compared to the general population (Figure 3). These researchers also conducted a case-control study using cases from the NIOSH-investigated CVD fatalities

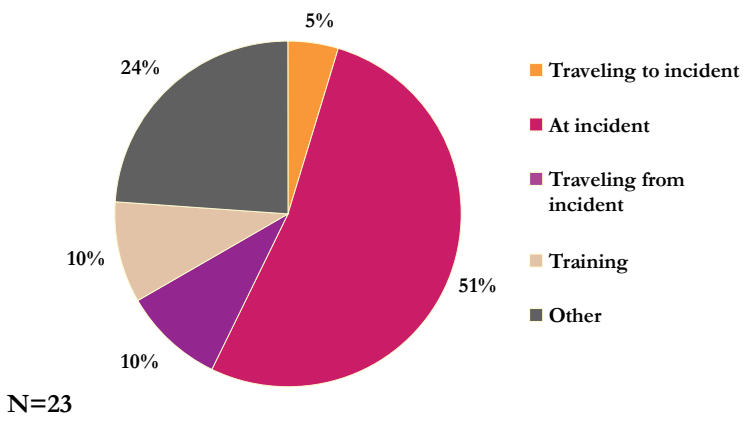

Figure 2. Fire fighter fatalities due to cardiovascular disease by activity.

and two control groups. They found a statistically significant increased risk during:

fire suppression [odds ratio $(\mathrm{OR})=64.1$, 95\% confidence interval (Cl) 7.4-556],

training [OR $=7.6,95 \% \mathrm{Cl} 1.8-31.3]$,

alarm response $[\mathrm{OR}=5.6,95 \% \mathrm{Cl} 1.1-$ 28.8], and

Strenuous physical activity on the job in the preceding 12 hours [OR $=3.2,95 \%$ Cl 1.4-7.2]. 


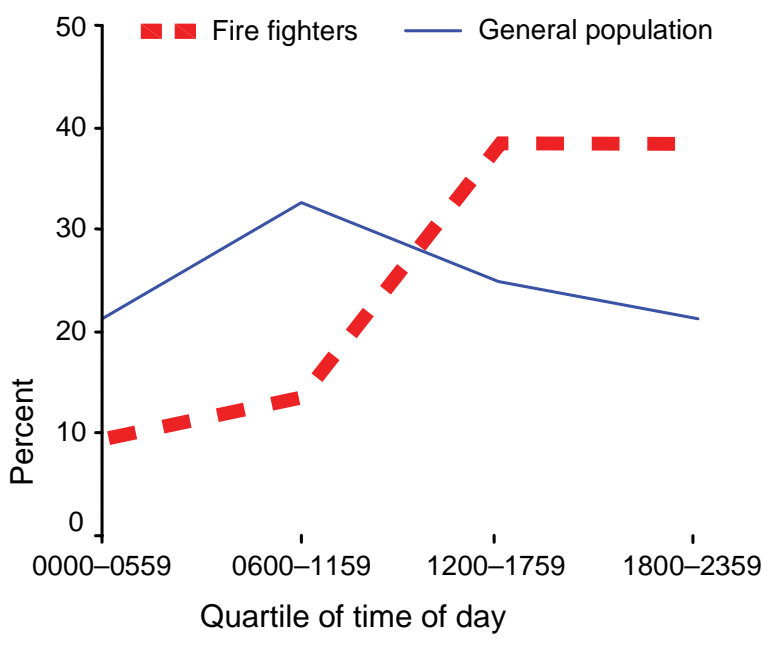

Figure 3. Circadian distribution of $\mathrm{CHD}$ deaths for fire fighters and the general population (Source: Kales et al. [2003]). ${ }^{\ddagger}$

A subsequent more extensive study by Kales et. al. found similar findings [Kales 2007]. These findings suggest that fatal heart attacks suffered by fire fighters while on-duty are work-related.

\section{Limitations}

$\mathrm{NIOSH}$ investigated $43 \%$ of all fire fighter fatalities due to CVD. Since career fire departments were overrepresented in the $\mathrm{NIOSH}$ investigated cases (65\%), selection bias may have influenced the findings. Specifically, the NIOSH findings may have over-reported the extent of medical evaluations, and fitness wellness program in the fire service since our data shows that career fire departments are more likely to have such programs compared to volunteer fire departments. On the other hand, the circadian and job activity distributions reported by the USFA from 1990-2000 were similar to that found in the NIOSH investigated cases [USFA 2002]. Therefore, this potential selection bias was

¥C2003 Kales et al.; license BioMed Central Ltd. This is an Open Access article: verbatim copying and redistribution of this article are permitted in all media for any prupose, provided this notice is preserved along with the article's original URL [http://www.ehjournal.net/content/2/1/14]

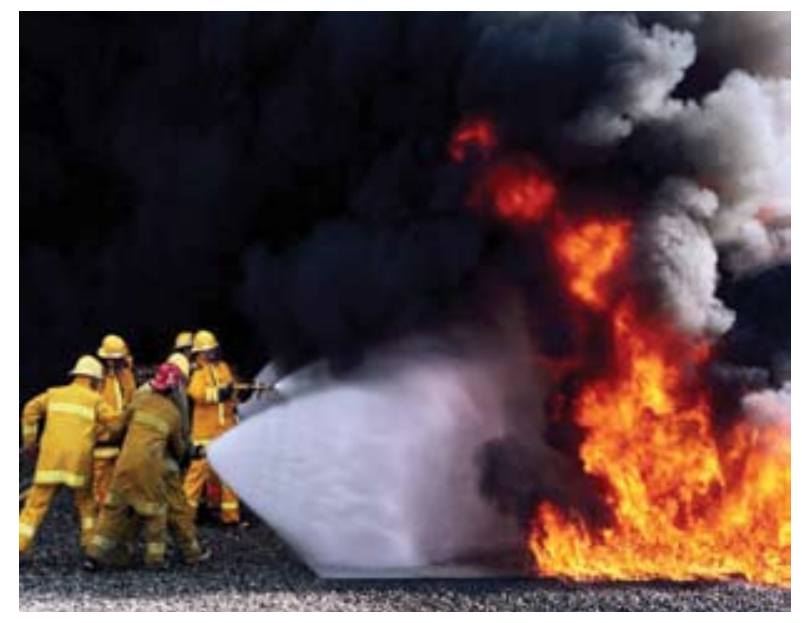

unlikely to have influenced findings regarding the work-relatedness of sudden cardiac deaths among fire fighters.

\section{CONCLUSIONS}

Fire fighters with medical conditions presenting a risk for sudden incapacitation pose a hazard to themselves, their co-workers, and civilians. Medical evaluations can diagnose these medical conditions. The fire service recommends medical evaluations and participation in comprehensive fitness and wellness programs to reduce the number of on-duty CVD fatalities. Findings from the NIOSH Fire Fighter Fatality Investigation and Prevention Program have documented that few fire departments experiencing onduty cardiac-related deaths of fire fighters have implemented member medical evaluation programs. Few have followed published guidelines regarding medical clearance for return-to-work. In addition, few have developed and encouraged participation in comprehensive fitness and wellness programs. These NIOSH findings were consistent with a subsequent USFA survey that report $76 \%$ of fire departments lacked programs to maintain basic fire fighter fitness and health [USFA 2006]. Obvious barriers 
to implementing these programs are costs, job security issues, and (for voluntary fire departments) maintaining a critical number of members. Additional research is needed to identify factors that can lower these barriers, thereby reducing the number of on-duty fire fighter fatalities due to CVD.

\section{RECOMMENDATIONS}

To reduce on-duty heart attacks and the risk of sudden cardiac events among fire fighters, $\mathrm{NIOSH}$ offers the following recommendations for (1) fire departments, (2) fire fighter candidates and fire fighters, and (3) fire service agencies. Many of these recommendations (e.g., the screening of fire fighters for CAD risk factors) are consistent with the general practice of preventive medicine [USPHS 1996]. Therefore, implementation of the following recommendations should not only reduce the number of on-duty fire fighter heart attacks and sudden cardiac events, but those occurring off-duty as well. ${ }^{\S}$

\section{Fire Departments}

\section{For Candidates:}

Provide post-offer/pre-placement medical evaluations to ensure that candidates are capable of performing job tasks with minimal risk of sudden incapacitation.

- Ensure that the physicians conducting the post-offer/pre-placement medical examinations are knowledgeable about the physical demands of fire fighting, the essential jobs tasks of fire fighting, and the

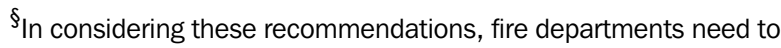
be aware of federal laws, such as the Americans with Disabilities Act of 1990, 29 U.S.C. 12101 et. seq. (ADA), as well as applicable state and local laws that may impact their implementation. For example, the ADA requires that medical examinations take place only after an offer of employment has been made.
}

consensus guidelines developed by the fire service [NFPA 2007].

Ensure that medical clearance for fullduty fire suppression and SCBA use is conducted by either (1) the fire department physician or (2) a primary care physician knowledgeable about the physical demands of fire fighting and the consensus guidelines developed by the fire service [NFPA 2007].

Ensure fire fighter candidates have the physical ability and capacity to perform the essential job tasks of fire fighting [IAFF/IAFC 1999].

Designate personnel to administer the fire department post-offer/pre-placement, and annual medical evaluations.

Refer candidates with cardiac conditions or coronary artery disease risk factors to their health care provider for further evaluation and treatment.

\section{For Fire Department Members:}

- Ensure fire fighters understand the importance of wearing respiratory protection during all phases of fire fightingfrom initial attack through overhaul.

Provide mandatory annual medical evaluations to ensure members are capable of performing job tasks with minimal risk of sudden incapacitation.

Ensure that physicians conducting the annual medical examinations are knowledgeable about the physical demands of fire fighting, the essential job tasks of fire fighting, and the consensus guidelines developed by the fire service [NFPA 2007]. 
- Ensure medical clearance for full-duty fire suppression and SCBA use is conduced by either (1) the fire department physician or (2) the primary care physician as previously noted. The medical clearance letter should state what essential job tasks the fire fighter can, and cannot, perform [NFPA 2007].

- Develop a comprehensive wellness/fitness program for fire fighters to reduce risk factors for CVD and improve cardiovascular capacity. The NFPA and the IAFF/IAFC documents can provide guidance.

- Encourage fire fighter participation in the fire department's wellness and fitness program.

- Ensure a smoking cessation program is included in any wellness program.

- Ensure that all fire stations and other fire department facilities are non-smoking facilities.

- Place and maintain AEDs on all fire department apparatus that are not equipped and staffed for manual defibrillation.

- Train fire fighters on the proper use of AEDs.

- Remind emergency department personnel and medical examiners to perform carboxyhemoglobin testing on all fire fighters who experience a cardiac arrest.

- Implement a comprehensive hearing conservation program which contains the following components: hazard identification and reduction, use of personal hearing protection devises, periodic audiograms, and fire fighter training on hearing conservation [Tubbs 1995].

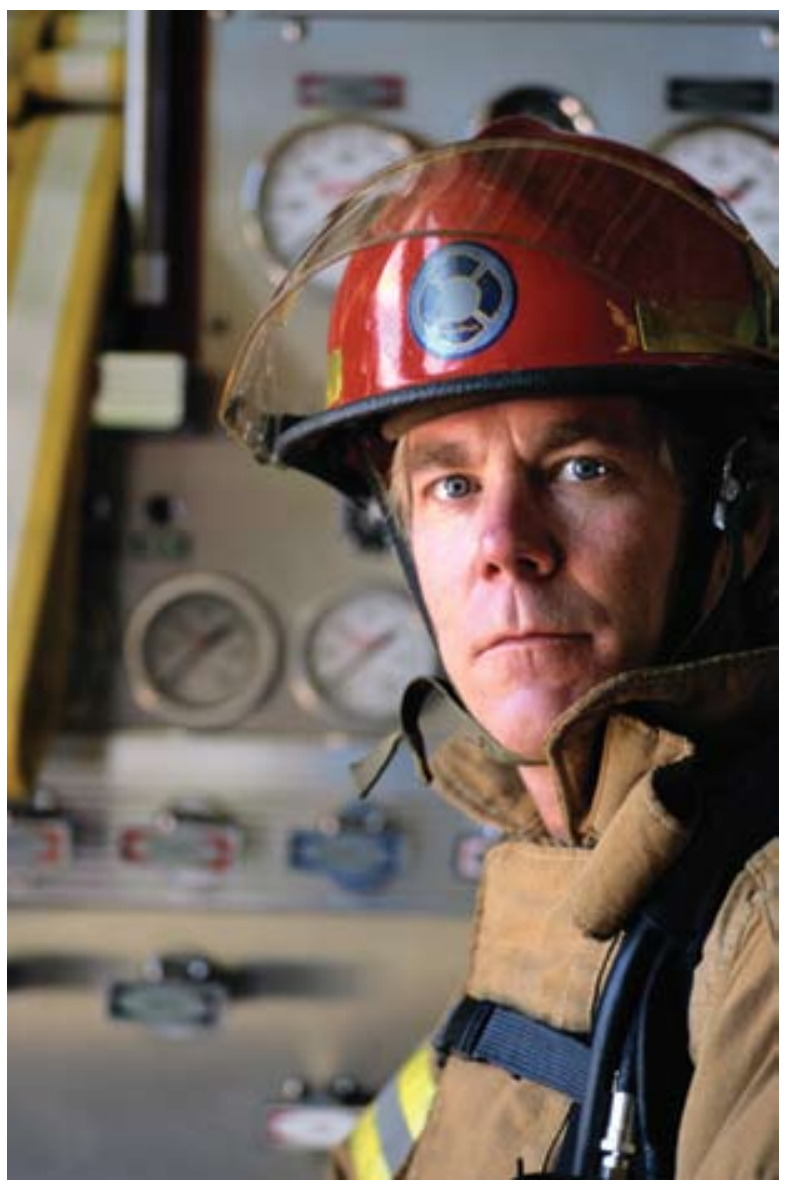

\section{During fire suppression and training operations:}

Control exposure to carbon monoxide and other fire contaminants through proper management of the fire scene and proper use of respiratory protection.

- Ensure adequate staffing levels for operations to prevent over-exertion and/or heat stress.

- Provide light weight equipment and personal protective gear to prevent overexertion and/or heat stress of the fire fighter.

Provide on-scene rehabilitation to monitor vital signs for indication of excessive cardiovascular strain, and to cool and hydrate the fire fighter. 
Ensure standby emergency medical care is available with transport capability.

\section{Fire Fighter Candidates and Fire Fighters}

- Participate in fire department fitness and wellness programs.

- For those with CAD risk factors, seek medical attention.

Share pertinent medical information with the fire department physician.

Report any new medical conditions, changes in the severity of an existing medical condition, or the use of prescription or over-the-counter medications to the fire department physician.

- Recognize the signs and symptoms of personal medical emergencies and know the appropriate course of action.

- Participate in fire department hearing conservation programs.

Wear personal hearing protection devices, when appropriate.

\section{Fire Service Agencies}

- Conduct research on the effectiveness of health promotion programs to reduce the incidence of heart disease among fire fighters.

- Conduct research on the barriers to implementing health promotion programs (both wellness and fitness) in the fire service.

- Conduct research on occupational exposures and the risk they pose to the cardiovascular system.
Conduct research into the effectiveness of on-scene rehabilitation to reduce cardiovascular strain.

Explore the feasibility of developing and routinely analyzing a nation-wide database composed of the mandatory annual medical evaluations conducted by fire departments.

\section{ACKNOWLEDGMENTS}

Principal contributors include Thomas Hales, Scott Jackson, and Tommy Baldwin of the Fire Fighter Fatality Investigation and Prevention Team, Division of Surveillance, Hazard Evaluations, and Field Studies. The authors would like to thank the following for their reviews of the document: Sandy Bogucki, Department of Emergency Medicine, Yale University; David Daniels, International Director, Health, Safety and Survival Section, IAFC; Richard Duffy, Assistant to the General President, IAFF; Rita Fahy, Manager, Fire Data Bases \& Systems, NFPA; Robert Goldberg, Medical Director, Los Angeles County; Jim Melius, Director, Laborers Health and Safety Fund; Daniel Samo, Chair, Public Safety Medicine Section, American College of Occupational and Environmental Medicine; Ronald Sarnicki, Executive Director, NFFF; Denise Smith, Chair, Department of Exercise Science, Skidmore College; Donald Stewart, Medical Director, Occupational Health Center, Fairfax County; William Troup, Fire Program Specialist, USFA; and Maggie Wilson, Director, Health and Safety, NVFC. Finally, the authors would like to thank the IAFF for supplying many of the photographs used in this document.

Roz Kendall, Donna Pfirman, Vanessa Becks, and Gino Fazio provided editorial and production services.

Please direct any comments, questions, or requests for additional information to the following: 
Dr. Teresa Schnorr, Director

Division of Surveillance, Hazard Evaluations and Field Studies

National Institute for Occupational Safety and Health

5555 Ridge Avenue

Cincinnati, OH 45226

Telephone: 513-841-4428 or call

1-800-35-NIOSH (1-800-356-4674)

We greatly appreciate your assistance in protecting the health of U.S. workers.

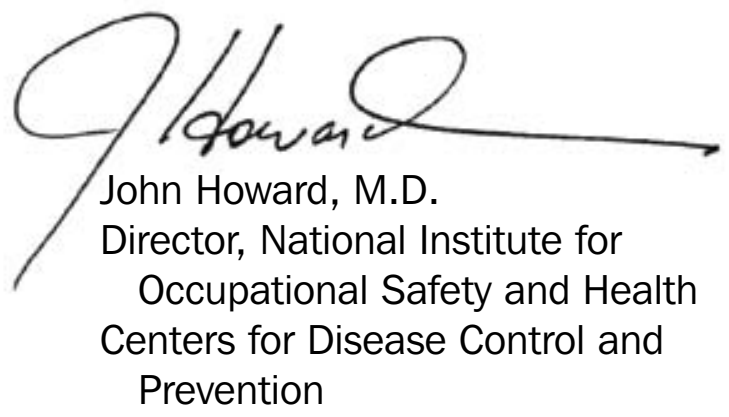

\section{REFERENCES}

AHA (American Heart Association) [2005]. 2005 American Heart Association Guidelines for Cardiopulmonary Resuscitation and Emergency Cardiovascular Care. Part 5: Electrical Therapies: Automated External Defibrillators, Defibrillation, Cardioversion, and Pacing. Circulation 112 (24 Supplement): IV-35.

AHA (American Heart Association) [2007]. Risk Factors and Coronary Artery Disease. http://www.americanheart.org/presenter. jhtml? identifier $=4726$ ] Date accessed February 26, 2007.

Akhtar MJ, al-Nozha M, al-Harthi S, Houh MS [1993]. Electrocardiographic abnormalities in patients with heat stroke. Chest 104:411414.
Albert CM, Mittleman MA, Chae CU, Lee IM, Hennekens CH, Manson JE [2000]. Triggering of sudden death from cardiac causes by vigorous exertion. N Engl J Med 343:13551361.

Allred EN, Bleecker ER, Chaitman BR, Dahms TE, Gottlieb SO, Hackney JD, PaganoM, Selvester RH, Walden SM, Warren J [1989]. Short-term effects of carbon monoxide exposure on the exercise performance of subjects with coronary artery disease. N Engl J Med 321:1426-1432.

Allred EN, Bleecker ER, Chaitman BR, Dahms TE, Gottlieb SO, Hackney JD, Pagano $\mathrm{M}$, Selvester RH, Walden SM, Warren J. [1991]. Effects of carbon monoxide on myocardial ischemia. Environ Health Perspect 91:89-132.

American Industrial Hygiene Association Technical Committee on Ergonomics [1971]. Ergonomics guide to assessment of metabolic and cardiac costs of physical work. Am Ind Hyg Assoc 560-564.

Arrighi HM, Hertz-Picciotto I [1994]. The evolving concept of the healthy worker survivor effect. Epidemiology 5:189-196.

Barnard RJ, Duncan HW [1975]. Heart rate and ECG responses of fire fighters. J Occup Med 17:247-250.

Bolstad-Johnson MD, Burgess JL, Crutchfield CD, Storment S, Gerkin R, Wilson JR [2000]. Characterization of firefighter exposures during fire overhaul. Am Ind Hyg Assoc J 61:636-641.

Brandt-Rauf PW, Fallon LF Jr, Tarantini T, Idema C, Andrews L [1988]. The health hazards of fire fighters: exposure assessment. Br J Ind Med 45:606-612.

Brook RD, Franklin B, Cascio W, HongY, Howard G, LIpsett M, Luepker R, Mittleman M, 
Samet J, Smith SC, Tager I [2004]. Air pollution and cardiovascular disease. A statement for healthcare professionals from the expert panel on population and prevention science of the American Heart Association. Circulation 109:2655-2671.

CA-EPA (Environmental Protection Agency) [2005]. Proposed identification of environmental tobacco smoke as a toxic air contaminant. Part B: Health effects. Sacramento (CA): California Environmental Protection Agency, Office of Environmental Health Hazard Assessment, 2005.

Calvert G, Merling JW, Burnett CA [1999]. Ischemic heart disease mortality and occupation among 16- to 60-year-old males. J Occup Environ Med 41(11):960-966.

CFR (Code of Federal regulations). Title 29 Part 1910, OSHA. Washington, DC: U.S. Government Printing Office, Office of the Federal Register.

Choi BCK [1992]. Definition, sources, magnitude, effect modifiers, and strategies of reduction of the healthy worker effect. J Occup Med 34:979-988.

Choi BCK [2000]. A technique to reassess epidemiologic evidence in light of the healthy worker effect: the case of firefighting and heart disease. J Occup Environ Med 42(10):1021-1034.

Davies HW, Teschke K, Kennedy SM, Hodgson MR, Hertzman C, Demers P [2005]. Occupational exposure to noise and mortality from acute myocardial infarction. Epidemiology 16:25-32.

Dockery DW, Pope DA, Xu X, Spengler JD, Ware JH, Fay ME, Ferris BG, Speizer FE [1993]. An association between air pollution and mortality in six US cities $\mathrm{N}$ Engl $\mathrm{J}$ Med 329:1753-1759.
Elliott WJm [2001]. Cyclic and circadian variations in cardiovascular events. Am J Hypertens 14:291S-295S.

Ernst A, Zibrak JD [1998]. Carbon monoxide poisoning. N Engl J Med 339:1603-1608.

Fahy R [2005]. U.S. firefighter fatalities due to sudden cardiac death, 1995-2004. Quincy, MA: National Fire Protection Association.

Feuer E, Roseman K [1986]. Mortality in police and firefighters in New Jersey. Am J Ind Med 9:517-519.

Finn JC, Jacobs IG, Holman CDJ, Oxer HF [2001]. Outcomes of out-of-hospital cardiac arrest patients in Perth, Western Australia, 1996-1999. Resuscitation 51:247-255.

Glasgow RE, Vogt TM, Boles SM [1999]. Evaluating the public health impact of health promotion interventions: The RE-AIM framework. Am J Public Health 89:1322-1327.

Gledhill N, Jamnik VK [1992]. Characterization of the physical demands of firefighting. Can J Spt Sci 17:207-213.

Guidotti TL [1992]. Human factors in firefighting: ergonomic, cardiopulmonary, and psychogenic stress-related issues. Int Arch Occup Environ Health 64:1-12.

Guidotti TL [1995]. Occupational mortality among firefighters: assessing the association. J Occup Environ Med 37:1348-1356.

Hales T, Baldwin T, Sexson K, Brown S [1999]. NIOSH Fire Fighter Fatality Investigation and Prevention Program. Unpublished paper presented at the IAFF Redmond Symposium, Honolulu, HI, August 26.

Hurley BH, Glasser SP, Phelps CP [1980]. Cardiovascular and sympathetic reactions to in-flight emergencies among base fire fighters. Aviat Space Environ Med 51:788792. 
IAFF, IAFC [1997]. The fire service joint labor management wellness/fitness initiative. Washington, DC: International Association of Fire Fighters, International Association of Fire Chiefs.

IAFF, IAFC [1999]. Candidate physical ability test. Washington, DC: International Association of Fire Fighters, International Association of Fire Chiefs.

Gold A, Burgess WA, Clougherty EV [1978]. Exposure of firefighters to toxic air contaminants. Am Ind Hyg Assoc 39:534-538.

Jankovic J, Jones W, Burkhart J, Noonan G [1991]. Environmental study of firefighters. Ann Occup Hyg 35:581-602.

Kales SN, Soteriades ES, Christoudias SG, Christiani DC [2003]. Firefighters and onduty deaths from coronary heart disease: a case control study. Environ health: a global access science source. 2:14. [http://www. ehjournal.net/content/2/1/14]. Date accessed: February 15, 2007.

Kales SN, Soteriades ES, Christophi CA, Christiani DC [2007]. Emergency duties and deaths from heart disease among fire fighters in the United States. N Eng J Med 356:1207-1215.

Karter Jr MJ, Molis JL [2006]. Fire Fighter Injuries-2005. Quincy, MA: National Fire Protection Association.

Kulig K [1991]. Cyanide antidotes and fire technology. New Eng J Med 325:18011802.

Kuorinka I, Korhonen O [1981]. Firefighters' reaction to alarm, an ECG and heart rate study. J Occup Med 23:762-766.

Lemon PW, Hermiston RT [1977]. The human energy cost of fire fighting. J Occup Med 19:558-562.
Levin BC, Kuligowski ED [2005]. Chapter 10. Toxicology of Fire and Smoke. National Institutes of Standards and Technology, Gaithersburg, MD. [http://fire.nist.gov/bfrlpubs/fire05/PDF/f05154.pdf] Date assessed: March 12, 2007.

Manning JE, Griggs TR [1983]. Heart rate in fire fighters using light and heavy breathing equipment: simulated near maximal exertion in response to multiple work load conditions. J Occup Med 25:215-218.

McNamee R, Burgess G, Dippnall WM, Cherry N [2006]. Occupational noise exposure and ischaemic heart disease mortality. Occup Environ Med 63:813-819.

Melius JM [1995]. Cardiovascular disease among firefighters. In: Orris P, Melius J, Duffy RM, eds. Firefighters' safety and health. Occupational Medicine State of the Art Reviews 10(4)821-827. Philadelphia, PA: Hanley \& Belfus, Inc.

Mittleman MA, Maclure M, Tofler GH, Sherwood JB, Goldberg RJ, Muller JE [1993]. Triggering of acute myocardial infarction by heavy physical exertion. $N$ Eng J Med 329:1677-1683.

NFPA [2000]. NFPA 1583: Standard on health-related fitness programs for fire fighters. Quincy, MA: National Fire Protection Association.

NFPA [2002a]. NFPA 1404: Standard for fire service respiratory protection training. Quincy, MA: National Fire Protection Association.

NFPA [2002b]. NFPA 1500: Standard on fire department occupational safety and health program. Quincy, MA: National Fire Protection Association. 
NFPA [2002c]. NFPA 1001: Standard for fire fighter professional qualifications. Quincy, MA: National Fire Protection Association.

NFPA [2007]. NFPA 1582: Standard on comprehensive occupational medical program for fire departments. Quincy, MA: National Fire Protection Association.

Nichol G, Stiell IG, Laupacis A, Pham B, De Maio VJ, Wells GA [1999]. A cumulative meta-analysis of the effectiveness of defibrillator-capable emergency medical services for victims of out-of-hospital cardiac arrest. Ann Emerg Med 34:517-525.

NIOSH [1985]. NIOSH/OSHA/USCG/EPA. Occupational Safety and Health Guidance Manual for Hazardous Waste Site Activities. U.S. Department of Health and Human Services, Public Health Service, Centers for Disease Control and Prevention, National Institute for Occupational Safety and Health Publication No. 85-115.

NIOSH [2000]. Fire fighter dies as a result of a cardiac arrest during a trench rescueGeorgia. Cincinnati, OH: U.S. Department of Health and Human Services, Public Health Service, Centers for Disease Control and Prevention, National Institute for Occupational Safety and Health, Fatality Assessment and Control Evaluation (FACE) Report 99F-49.

NIOSH [2001]. Fire fighter dies after completing job task evaluation-Alabama. Cincinnati, OH: U.S. Department of Health and Human Services, Public Health Service, Centers for Disease Control and Prevention, National Institute for Occupational Safety and Health, Fatality Assessment and Control Evaluation (FACE) Report F2001-25.

NIOSH [2003]. Fire fighter dies during live fire training-North Carolina. Cincinnati, $\mathrm{OH}$ : U.S. Department of Health and Human Services, Public Health Service, Centers for
Disease Control and Prevention, National Institute for Occupational Safety and Health, Fatality Assessment and Control Evaluation (FACE) Report F2002-19.

NIOSH [2004]. Fire fighter dies during performing service call-Connecticut. Cincinnati, OH: U.S. Department of Health and Human Services, Public Health Service, Centers for Disease Control and Prevention, National Institute for Occupational Safety and Health, Fatality Assessment and Control Evaluation (FACE) Report F2004-7.

NIOSH [2005]. Fire chief suffers sudden cardiac death while returning to the fire station after a structure fire. Cincinnati, OH: U.S. Department of Health and Human Services, Public Health Service, Centers for Disease Control and Prevention, National Institute for Occupational Safety and Health, Fatality Assessment and Control Evaluation (FACE) Report F2005-11.

NVFC (National Volunteer Fire Council) [2004a]. Healthy-heart initiative. [http:// www.healthy-firefighter.org]. Date accessed: February 15, 2007.

NVFC, USFA [2004b]. Health and wellness guide for the volunteer fire service, Emmitsburg, MD: Federal Emergency Management Agency; United States Fire Administration, Publication No. FA-267/January 2004. [http://www.usfa.fema.gov/downloads/pdf/ publications/fa-267.pdf] Date accessed: February 15, 2007.

NFFF (National Fallen Firefighter Foundation) [2007]. Everyone Goes Home Firefighter Life Safety Initiative. [www.everyonegoeshome.com] Date accessed: March 9, 2007.

Paffenbarger RS Jr, Hyde RT, Wing AL, Lee IM, Jung DL, Kampert JB [1993]. The association of changes in physical-activity level and 
other lifestyle characteristics with mortality among men. N Engl J Med 32:538-545.

Pantadosi CA [2002]. Carbon monoxide poisoning. N Eng J Med 347:1054-1055.

Pelletier KR [2001]. A review and analysis of the clinical- and cost-effectiveness studies of comprehensive health promotion and disease management programs at the worksite: 1998-2000 update. Am J HIth Promot 16:107-116.

Pelletier KR [1996]. A review and analysis of the clinical- and cost-effectiveness studies of comprehensive health promotion and disease management programs at the worksite: 1993-1995 update. Am J Hlth Promot 10:380-388.

Peters A, Dockery DW, Muller JE, Mittleman MA [2001]. Increased particulate air pollution and triggering of myocardial infarction. Circulation 103:2810-2815.

Pope CA III, Burnett RT, Thun MJ, Calle EE, Krewski D, Ito K, Thurston GD [2002]. Lung cancer, cardiopulmonary mortality, and longterm exposure to fine particulate air pollution. JAMA 287:1132-1141.

Pope CA III, Burnett RT, Thurston GD, Thun MJ, Calle EE, Krewski D, Godleski JJ [2004]. Cardiovascular mortality and long-term exposure to particulate air pollution: epidemiological evidence of general pathophysiological pathways of disease. Circulation 109:71-77.

Pope CA III, Muhlestein JB, Heidi TM, Renlund DG, Anderson JL, Horne BD [2006]. Ischemic heart disease events triggered by short-term exposure to fine particulate air pollution. Circulation 114:2443-2448.

Purser DA, Grimshaw P, Berrill KR [1984]. Intoxication by cyanide in fires: A study in monkeys using polyacrylonitrile. Arch Environ Health 39:394-400.

Rossi R [2003]. Fire fighting and its influence on the body. Ergonomics 46:1017-1033.

Sandvik L, Erikssen J, Thaulow E, Erikssen G, Munda R, RodahIK [1993]. Physical fitness as a predictor of mortality among healthy, middle-aged Norwegian men. N Engl J Med 328:533-537.

Satran D, Henry CR, Adkinson C, Nicholson $\mathrm{Cl}$, Yiscah B, Henry TD [2005]. Cardiovascular manifestations of moderate to severe carbon monoxide poisoning. J Am Coll Cardiol 45:1513-1516.

Siscovick DS, Weiss NS, Fletcher RH, Lasky $T$ [1984]. The incidence of primary cardiac arrest during vigorous exercise. N Eng J Med 311:874-877.

Smith DL, Petruzzello SJ, Manning TS [2001]. The Effect of Strenuous Live-Fire Drills on Cardiovascular and Psychological Responses of Recruit Firefighters. Ergonomics 44:24 4-254.

Steenland K [2000]. Shift work, long hours, and SCD: a review. Research finding linking workplace factors to CVD outcomes. In: Schnall PL, Belkic K, Landsbergis P, Baker $D$, eds. The workplace and cardiovascular disease. Occupational Medicine State of the Art Reviews 15(1):7-17. Philadelphia, PA: Hanley \& Belfus, Inc.

Stiell IG, Wells GA, De Maio VJ, Spaite DW, Field BJ 3rd, Munkley DP, Lyver MB, Luinstra LG, Ward R. [1999a]. Modifiable factors associated with improved cardiac arrest survival in a multicenter basic life support/ defibrillation system: OPALS Study Phase I results. Ontario Prehospital Advanced Life Support. Ann Emerg Med 33:44-50. 
Stiell IG, Wells GA, Field BJ, Spaite DW, De Maio VJ, Ward R, Munkley DP, Lyver MB, Luinstra LG, Campeau T, Maloney J, Dagnone E, OPALS Study Group [1999b]. Improved out-of-hospital cardiac arrest survival through the inexpensive optimization of an existing defibrillation program: OPALS Study Phase II. JAMA 281:1175-1181.

Tofler GH, Muller JE, Stone PH, Forman S, Solomon RE, Knatterud GL, Braunwald E [1992]. Modifiers of timing and possible triggers of acute myocardial infarction in the Thrombolysis in Myocardial Infarction Phase II (TIMI II) Study Group. J Am Coll Cardiol 20:1049-1055.

Treitman RD, Burgess WA, Gold A [1980]. Air contaminants encountered by fire fighters. Am Ind Hyg Assoc J 41:796-802.

Tubbs RL [1995]. Noise and hearing loss in firefighting. In: Orris P, Melius J, Duffy RM, eds. Firefighters' safety and health. Occupational Medicine State of the Art Reviews 10(4)843856. Philadelphia, PA: Hanley \& Belfus, Inc.

USDHHS (U.S. Department of Health and Human Survices) [2006]. The health consequences of involuntary exposure to tobacco smoke. [www.surgeongeneral.gov/ library/secondhandsmoke/report/fullreport. pdf] Date accessed: Febuary 23, 2007.

USEPA (U.S. Environmental Protection Agency) [1992]. Review of national ambient air quality standards for carbon monoxide. Assessment of scientific and technical information, pp. 15-22. [http://www.epa.gov/ ttn/naaqs/standards/co/data/cosp1992. pdf]. Date accessed: February 15, 2007.

USFA (U.S. Fire Administration) [2002]. Firefighter fatality retrospective study, 19902000. Emittsburg, MD: Federal Emergency Management Agency, U.S. Fire Administration,
Publication No. FA-220. [http://www.usfa. dhs.gov/downloads/pdf/publications/fa-220. pdf] Date accessed: February 15, 2007.

USFA (U.S. Fire Administration) [2006] Four Years Later-A Second Needs Assessment of the U.S.Fire Service. Emittsburg, MD: Federal Emergency Management Agency, U.S. Fire Administration, Publication No. FA-303. [http://www.nfpa.org/assets/files/ PDF/NeedsAssessment2NatIReportFA303. pdf] Date accessed: April 26, 2007.

U.S. Preventive Services Task Force [1996]. Guide to clinical prevention services, 2nd ed. Baltimore, MD: Williams \& Wilkins.

Valenzuela TD, Roe DJ, Cretin S, Spaite DW, Larsen MP [1997] Estimating effectiveness of cardiac arrest interventions: a logistic regression survival model. Circulation 96:3308-3313.

Van Kempen EE, Kruize $\mathrm{H}$, Boshuizen $\mathrm{HC}$, Ameling CB, Staatsen BAM, DeHollander AEM [2002]. The association between noise exposure and blood pressure and ischemic heart disease: a meta-analysis. Environ Health Perspect 110:307-310.

White RD, Hankins DG, Bugliosi TF [1998]. Seven years' experience with early defibrillation by police and paramedics in an emergency medical services system. Resuscitation 39:145-151.

Willich SN, Lewis M, Lowel H, Arntz HR, Schubert F, Schroder R [1993]. Physical exertion as a trigger of acute myocardial infarction. N Eng J Med 329:1684-1690.

Willich SN, Wegscheider K, Stallmann M, Keil T [2006]. Noise burden and the risk of myocardial infarction. Eur Heart J 27:276282 
NOTES

Fire Fighter Fatalities 
NOTES 


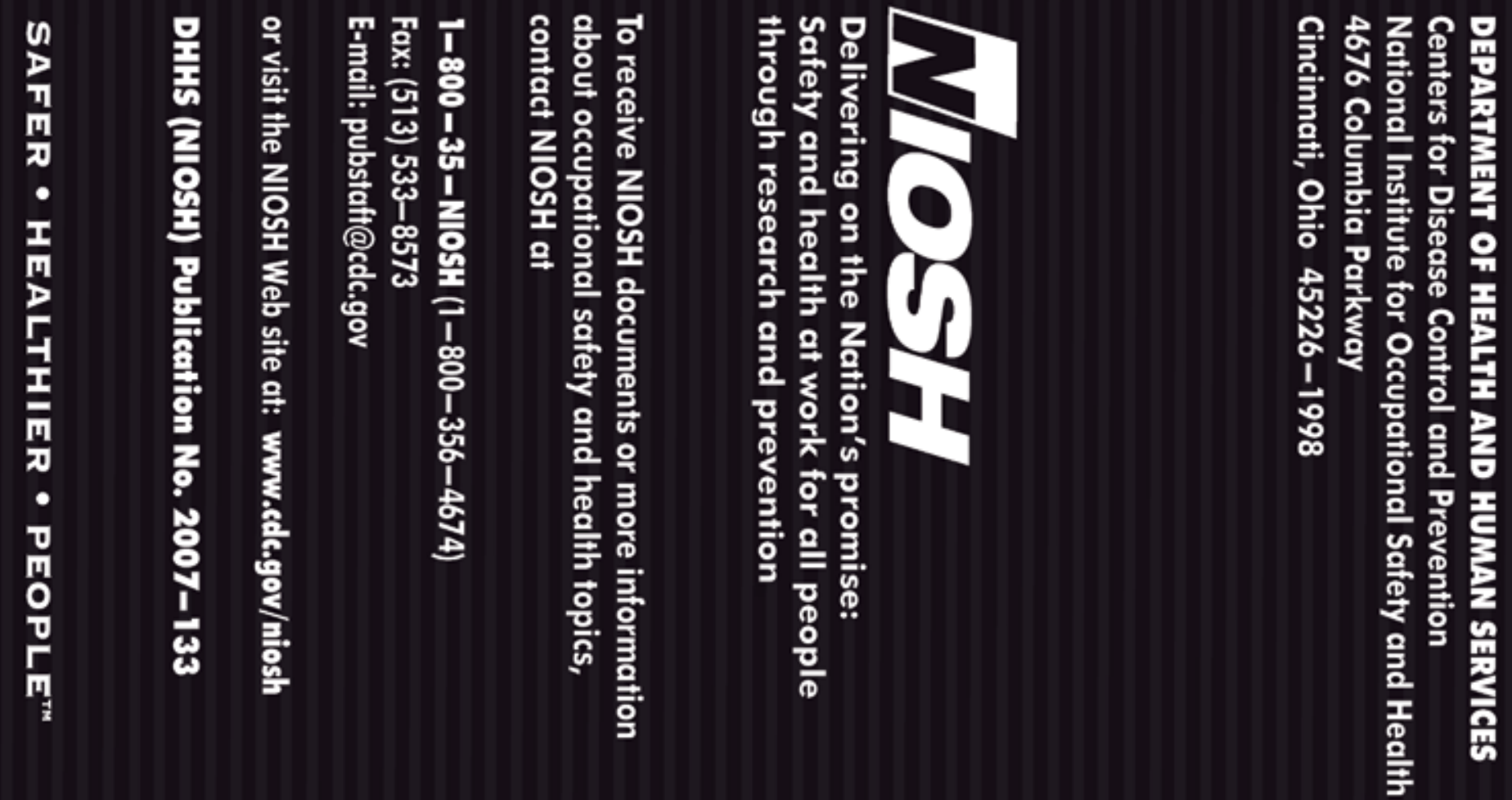